\title{
Analysis of multi-decadal wetland changes, and cumulative impact of multiple storms 1984 to 2017
}

\author{
Steven H. Douglas $\mathbb{D} \cdot$ Julie C. Bernier $\mathbb{D} \cdot$ Kathryn E. L. Smith
}

Received: 16 October 2017 / Accepted: 10 October 2018/Published online: 9 November 2018

(C) The Author(s) 2018

\begin{abstract}
Land-cover classification analysis using Landsat satellite imagery acquired between 1984 and 2017 quantified short- (post-Hurricane Sandy) and long-term wetland-change trends along the Maryland and Virginia coasts between Metompkin Bay, VA and Ocean City, MD. Although there are limited options for upland migration of wetlands in the study area, regression analysis showed that wetland area increased slightly between 1984 and 2011, indicating that marsh aggradation rates were sufficient to maintain wetland elevation relative to mean sea level. Following Hurricane Irene (August 2011), the Halloween Nor'Easter (October 2011), and Hurricane Sandy (October 2012), wetland area decreased by more than $7 \mathrm{~km}^{2}$ compared with average pre-storm extents. We assume that Hurricane Sandy had the greatest impact due to the size and intensity of the storm. However, the cumulative effects of multiple storms within a short time period likely contributed to
\end{abstract}

Electronic supplementary material The online version of this article (https://doi.org/10.1007/s11273-018-9635-6) contains supplementary material, which is available to authorized users.

S. H. Douglas $(\bowtie)$

Cherokee Nation Technologies, St. Petersburg, FL 33701,

USA

e-mail: sdouglas89.sd@gmail.com

J. C. Bernier · K. E. L. Smith

St. Petersburg Coastal and Marine Science Center, U.S.

Geological Survey, St. Petersburg, FL 33701, USA the greater observed losses in coastal wetlands relative to earlier periods. Five years after Hurricane Sandy, wetland area had not significantly recovered, but more time may be necessary to assess if the observed wetland losses will persist or if new growth within flooded marsh areas will be sufficient for the wetlands to recover to pre-storm extents. Comparisons of longterm and storm-driven wetland changes can lead to improved accuracy of habitat vulnerability models and greater understanding of potential impacts of future storms and SLR to coastal wetlands.

Keywords Wetlands - Landsat - Hurricane . Nor'Easter

\section{Introduction}

Coastal wetlands provide substantial economic and ecological services to communities but are under increasing threat from sea-level rise (SLR) (Craft et al. 2009; Darwin and Tol, 2001; Howes et al. 2010; Crosby et al. 2016; Enwright et al. 2016; Ganju et al. 2017; Jankowski et al. 2017), extreme storms (Michener et al. 1997; Cahoon 2006; Day et al. 2008; Leonardi et al. 2016; Walters and Kirwan 2016), climate change, and urbanization (Lee et al. 2006; Li et al. 2009). These impacts are particularly acute along the densely populated U.S. Atlantic coast (Wilson and 
Fischetti 2010). SLR in the mid-Atlantic coast region of North America is as much as twice the global average (DeJong et al. 2015; Sallenger et al. 2012). As sea-level rises and population increases, the risk of wetland loss from shoreline erosion and (or) submergence also increases (DeLaune et al. 1994; Neumann et al. 2015).

Salt marshes cover extensive areas of the midAtlantic coast, particularly along protected backbarrier and mainland estuarine shorelines. These are among the most productive, but also some of the most threatened ecosystems on Earth (Craft et al. 2009; Halpern et al. 2008; Lotze et al. 2006; Mitsch and Gosselink, 2000). Historically, coastal wetlands maintained elevation relative to mean sea level (MSL) through accretion (Chapman 1960; Letzsch and Frey 1980; Pethick 1981) or inland migration (Brinson et al. 1995; Donnelly and Bertness 2001; Kirwan and Megonigal 2013). If accretion is less than SLR, then wetlands are at risk of submergence (DeLaune et al. 1983; Warren and Niering 1993; Morris et al. 2002). In addition to physiographic and morphologic controls that prevent inland migration, recent coastal zone development also restricts wetland migration and influences sediment dynamics in coastal waters (Nicholls et al. 1999; Cahoon 2006; French 2006). Recently, due to accelerating SLR rates, decreasing accretion rates, and limited opportunity for landward migration, wetland submergence has become an increasing problem (Crosby et al. 2016). Worldwide, up to $50 \%$ of salt marshes have been lost or degraded since 1900 due to the combined effects of submergence, erosion, and reclamation (Kirwan and Megonigal 2013; MEA 2005; UNEP 2006). The loss of coastal wetlands affects the number of viable fisheries and nursery habitats as well as filtering and detoxification services provided by the diverse flora and fauna community (Worm et al. 2006), affect coastal geomorphological processes, and contribute to decreased protection from coastal hazards (Barbier et al. 2011; Braatz et al. 2007; Cochard et al. 2008; King and Lester 1995; Koch et al. 2009).

Estuarine shorelines along the mid-Atlantic coast are typically marsh-dominated ecosystems that are protected from high-energy waves. During storm events, however, high-velocity winds, surge, and waves within the estuary may erode the back-barrier shoreline and (or) deliver sediments to the barrier island interior if the ocean-side beaches and dunes are overwashed. Overwash processes can bury existing wetland vegetation but may also provide sediment for shoreline building, wetland accretion, and landward wetland migration if the washover deposits reach the estuary. While storms may provide benefits to healthy wetlands systems (McKee and Cherry 2009; Turner et al. 2006), the impact of multiple storms within a short time can impede post-storm wetland recovery and increase likelihood of wetland loss (Morton and Barras 2011).

After making landfall as a Category 1 hurricane in eastern North Carolina, Hurricane Irene (18/Aug/ 2011) tracked along the coast, damaging mid-Atlantic states with high winds and storm surge (Avila and Cangialosi 2011). Two months after Hurricane Irene, the Halloween Nor'Easter (29/Oct/2011) produced near-hurricane-force winds and brought heavy winter precipitation to the mid-Atlantic coastal states (Roth 2011; Ryan 2011). One year later, Hurricane Sandy (29/Oct/2012) made landfall near Brigantine, New Jersey. Hurricane Sandy tracked approximately parallel to the U.S. Atlantic coast, impacting the coastline from North Carolina to Massachusetts with rain, wind, waves, and storm surge. Coastal areas in Maryland and Virginia received over 8 inches of rain with sustained winds up to 50 knots and maximum storm surge of about $1.5 \mathrm{~m}$ above mean higher high water (NOAA 2012; Blake et al. 2013).

Quantifying spatial and temporal patterns of coastal wetland change advances our understanding of storm impacts and evaluation of wetland resilience under different climate and SLR scenarios. Multispectral imagery from Landsat Thematic Mapper (TM; Landsat 5 and 7 missions) and Operational Land Imaging (OLI; Landsat 8) satellites provide a consistent, medium resolution (30-m pixel size), multi-decadal data source to efficiently and inexpensively monitor land-cover change. Although higher resolution satellite imagery and aerial photography might improve delineation of tidal creeks, small interior-wetland ponds, small-scale overwash fans, or localized marshedge erosion, Landsat imagery is preferred for regional multi-temporal land-cover classification and land-change analyses (e.g., Homer et al. 2007, 2015; Fry et al. 2011; Hansen and Loveland 2012; Wulder et al. 2012; Jin et al. 2013; Fickas et al. 2016).

The primary objectives of this study were to: (1) examine Hurricane Sandy-induced wetland change relative to long-term trends for Assateague Island and 
the surrounding region; and (2) provide new data that can support future assessments on the long-term impact of storms and rising sea level on wetland resilience, post-storm recovery, and estuarine wetland change.

\section{Study area}

The study area between Metompkin Bay, Virginia and Ocean City Inlet, Maryland, includes barrier-island and mainland estuarine wetlands and beaches but excludes urban areas on Chincoteague Island (Fig. 1). Intertidal estuarine and barrier-island wetland vegetation in the study area includes a mix of cordgrass (Spartina alterniflora) and saltgrass (Distichilis spicata) (Erwin et al. 2004; Carruthers et al. 2011). High marsh (tidal wetlands that flood only when local tides exceed mean high water [MHW]) throughout the study area is dominated by salt meadow hay (Spartina patens), Olney's three-square (Scirpus americanus), salt grass (Distichlis spicata), and glasswort (Salicornia spp.). Shrubs that occur in the high marsh include marsh elder (Iva frutescens) and saltbush (Baccharis halmifolia) (Wilson et al. 2007). Inland wetlands on the barrier islands are small, less persistent, mostly fresh, and populated by narrow-leaved cattail (Typha angustifolia) and the invasive Phragmites (Phragmites australis) (Carruthers et al. 2011).

Assateague Island is a wave-dominated barrier island that is susceptible to erosion and overwash during storms (Carruthers et al. 2011; Schupp et al. 2013). In the southern part of the study area, Wallops, Assawoman, and Metompkin Islands, are sandstarved, mixed-energy barrier islands that are offset several kilometers inland from Assateague Island (Kranz et al. 2016) and are separated from the mainland uplands by estuarine marshes and bays. Although hurricanes rarely make landfall in the study area, waves and storm surge from offshore tropical systems as well as extratropical Nor'Easters may cause significant coastal change (Schupp et al. 2013). Most studies of storm impacts along this coastline have focused on storm-induced beach erosion and overwash, especially along the northern part of Assateague Island (e.g., Munger and Kraus 2010; Schupp et al. 2013), vegetative response following washover deposition (e.g., Wolner et al. 2013; Walters and Kirwan 2016), or marsh-edge erosion as a function
Fig. 1 a April 1985 and b April 2017 Landsatderived water, total wetland, forested, and total bare earth land-cover classifications. Numbered features are (1) Assawoman Island, (2) Wallops Island, (3) Chincoteague Inlet, (4) Tom's Cove, (5) Johnson Bay, (6) Assateague Island, (7) Newport Bay, and (8) Ocean City Inlet. Inset map displays the locations of tidal gages used in this study

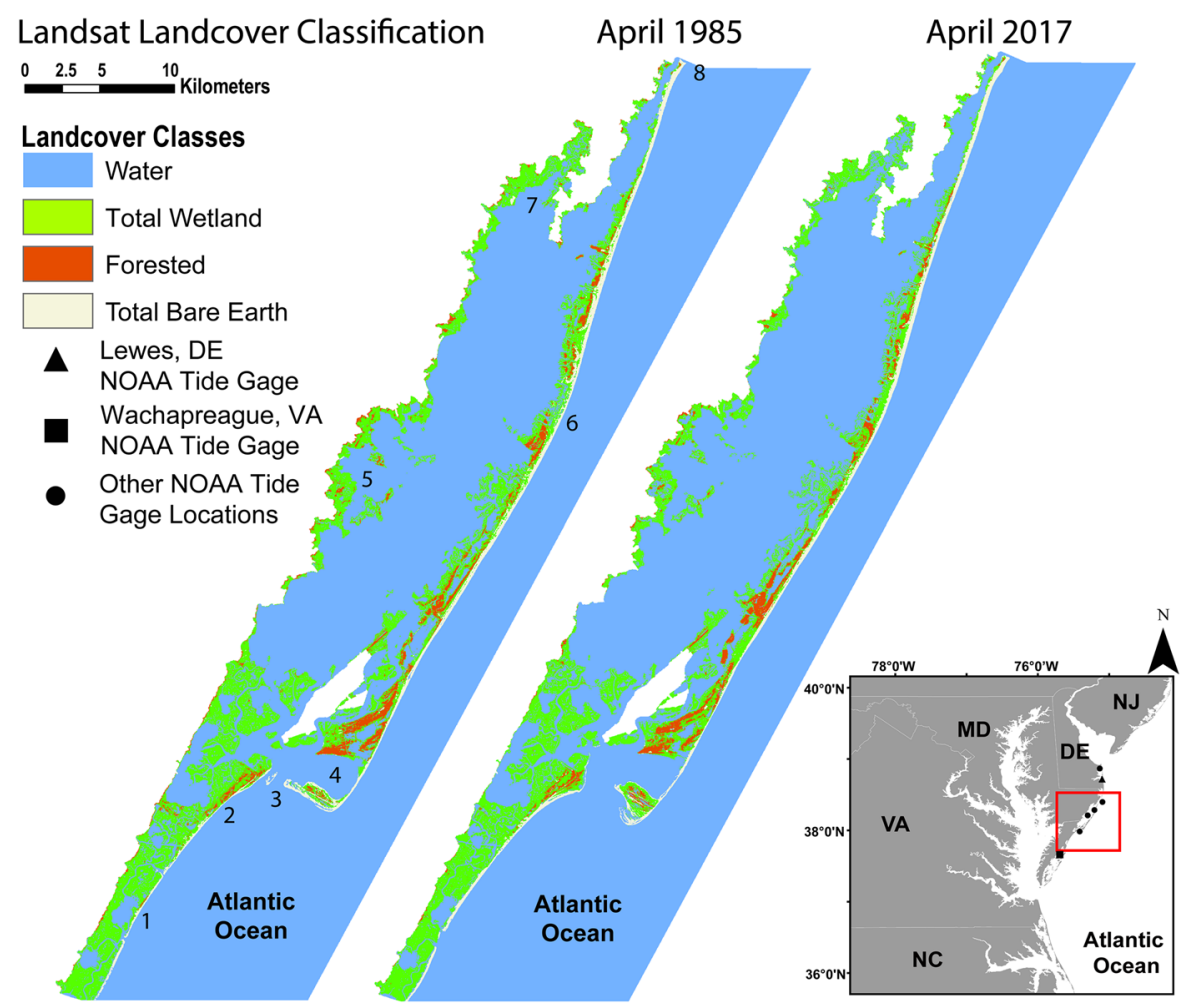


of wave energy (e.g., McLoughlin et al. 2015; Leonardi and Fagherazzi 2014; Priestas et al. 2015) but not the long-term response of wetland extent to multiple storm impacts. Prior to Hurricane Sandy, many barrier islands in the study area were fronted by berms and dunes ranging from about $2-4.5 \mathrm{~m}$ in height. Storm surge eroded the lower-elevation dunes and delivered clastic sediment to the back-barrier environments. In some locations, the washover deposits extended across Assateague Island to Chincoteague Bay (Sopkin et al. 2014).

\section{Methods}

Image selection, processing, and classification methods are detailed in Bernier et al. (2015). Fourteen Landsat 5 TM and four Landsat 8 OLI images acquired during spring or late fall between 1984 and 2017 were analyzed [Worldwide Reference System 2 (WRS-2) path 14 row 33 and path 14 row 34]. Two datasets (5/ May/1999 and 15/November/2004) presented in Bernier et al. (2015) were excluded from this analysis because visual inspection showed excessive flooding of both wetland and bare earth (beach) environments, indicating high-water conditions at the time of image acquisition. Due to the failure of the scan line corrector on the Landsat 7 satellite in May 2003 (U.S. Geological Survey 2012) and the decommissioning of Landsat 5, there is a 2-year gap between useable images acquired in April 2011 and April 2013, and the effects of Hurricane Irene, the Halloween Nor'Easter, and Hurricane Sandy were assessed collectively.

Each scene was stacked into a multi-band composite image and converted to at-sensor radiance and topof-atmosphere reflectance to reduce scene-to-scene variability (Chavez 1988, 1989, 1996; Chander et al. 2009). Adjacent scenes were mosaicked and clipped to the study-area extent and classified using a modified progressive classification scheme (Jensen et al. 1987; Ramsey and Laine 1997) to improve separation of the non-water classes. Application of a $3 \times 3$ edge enhancement convolution filter increased the contrast between water and non-water pixels (Braud and Feng 1998, Barras et al. 2003). Unsupervised classification of the edge-enhanced image was performed and pixels that were classified as water were masked from the original, non edge-enhanced image. Subsequent unsupervised classification of the remaining pixels generated 50 spectral clusters for each image date, which were reduced to seven land-cover classes based on visual interpretation. Qualitative assessment of the data presented in Bernier et al. (2015) indicated that the final classed datasets commonly included noise, or "speckling," within open-water bodies that resulted from misclassification of submerged tidal flats or submerged aquatic vegetation as wet marsh. Prior to analysis, we applied a band 5 density slice (e.g., Allen et al. 2012; Braud and Feng 1998; Barras et al. 2003, Frazier and Page 2000) to further separate land and water areas and remove noise from open-water bodies.

The final classification (Bernier et al. 2015) included water, wet marsh, marsh, forested, mixed vegetation, vegetated bare earth, and bare earth classes. Wet marsh is a sub-category of marsh that is visibly wetter than the surrounding marsh and may include submerged marsh areas and can be differentiated from water by the adsorption of mid-infrared and near-infrared wavelengths and higher spectral reflectance of infrared (Bernier et al. 2006). Mixed vegetation refers to relatively high reflectance pixels that Bernier et al. (2015) interpreted as mixed high marsh and woody scrub/shrub vegetation. Vegetated bare earth includes areas with sparse vegetative coverage or short grasses such as American dune grass (Ammophila breviligulata).

Although the primary goal of this study was to quantify wetland-change trends, the original classification scheme (Bernier et al. 2015) included additional land-cover classes as part of a larger assessment of storm-induced overwash and coastal-vulnerability model sensitivity. The additional classes may also help explain land-cover changes and identify classification errors. To assess land-cover changes, we grouped wet marsh plus marsh and vegetated bare earth plus bare earth into total marsh and total bare earth classes, respectively. Total wetland area was calculated by grouping total marsh with mixed vegetation classes (Tables 1, S1 [online supplemental information]).

\section{Accuracy assessment}

Accuracy assessments were performed for six landcover datasets with temporally consistent reference aerial photography. Random sample points $(\mathrm{N}=195)$ were generated based on binomial probability theory (Eq. 1) (Fitzpatrick-Lins, 1981): 
Table 1 Land-cover classes used in trends analyses (this paper) derived from Bernier et al. (2015) source classification scheme

\begin{tabular}{lll}
\hline Bernier et al. (2015) classification & Land-cover class (this paper) & Change analysis value (this paper) \\
\hline 0-Out & Out & 0-Out \\
1-Water & Water & 1-Water \\
4-Wet marsh & Total marsh & 3-Total wetland \\
6-Marsh & Total marsh & 3-Total wetland \\
7-Forested & Forested & 7-Not wetland \\
9-Mixed vegetation & Mixed vegetation & 3-Total wetland \\
10-Vegetated bare earth & Total bare earth & 7-Not wetland \\
11-Bare earth & Total bare earth & 7-Not wetland \\
\hline
\end{tabular}

$N=\frac{z^{2}(p)(q)}{E^{2}}$

where $\mathrm{N}$ is the number of samples to generate, $\mathrm{z}=$ standard normal deviate for $95 \%$ two-tail confidence level (1.96), $\mathrm{p}=$ expected accuracy (85), $\mathrm{q}=100-\mathrm{p}$, and $\mathrm{E}=$ allowable error (5).

Using high-resolution aerial photographs from 1989, 2005, 2009, 2011, 2013, and 2015 as ancillary data, each point was visually examined to assess if the pixel was classified correctly. The sample points were joined with the land-cover data using the Spatial Analyst Extract Values to Points tool in ESRI ArcGIS and points overlying wetland and non-wetland areas were assigned a value of 1 and 0 , respectively. A second assessment was performed using the 2011 National Land Cover Database (NLCD; Homer et al. 2015). For this analysis, the sample points were joined with the land-cover data from this study and the NLCD data using the Spatial Analyst Extract Multi Values to Points tool in ArcGIS. The data from both datasets were then reduced to water, total wetland, and not wetland classes for comparison.

\section{Water-level data}

Daily and monthly water-level data for 1980 through 2017 were downloaded from National Ocean Service (NOS) Center for Operational Oceanographic Products and Services (CO-OPS) stations 8557380 (Lewes, DE) and 8631044 (Wachapreague, VA) (Fig. 1), which are the closest long-term gauges with continuous high resolution water-level data for the study period (NOAA 2018). Tidal-stage and tidal-range data for three long-term stations (Lewes, DE; Ocean City,
MD; and Wachapreague, VA) and five short-term stations (South Point, MD, Public Landing, MD, Buntings Bridge, MD, Jesters Island, VA, and the U.S. Coast Guard [USCG] Station) within Chincoteague Bay were also compiled.

\section{Wetland change}

Wetland-change trends were evaluated across the entire study area as well as the subset areas of (a) Chincoteague Bay estuarine wetlands (including Assateague Island), and (b) mainland and estuarine wetlands south of Chincoteague Bay (Wallops to Metompkin Islands). The relationship between water levels and wetland- or land-area trends were examined using both linear regression and Spearman rank correlation analyses. Linear regression and analysis of variance (ANOVA) statistics were applied to evaluate historical trends.

Wetland change was further evaluated by assessing two metrics: wetland persistence and land-cover switching. To assess wetland persistence, the total marsh and mixed wetland vegetation classes for each land-cover raster were reclassified as 1 (wetland presence) and all other classes were reclassified as 0 (wetland absence). When the baseline data (1985) is subtracted from a later dataset, the outcome results in cells with three possible values: 0 (no change), 1 (wetland gain), or -1 (wetland loss) (Douglas et al. 2017). The sum of all two-date comparisons (1985-1989, 1985-1994, etc.) results in a raster with cells ranging from 10 to -10 , where 10 is persistent, long-term gain and -10 is persistent, long-term loss. Intermediate values may indicate short-term or recent losses or gains. 
To evaluate land-cover switching, land-cover types were reclassified as 1 (water), 3 (wetland), or 7 (nonwetland) (Table 1). These values were chosen so that the results of subtracting two dates will create unique values for each scenario. For example, if a cell in 1994 is classified as land and in 1989 was wetland, the result (1994-1989 or 7-3) is 4. With this analysis, each twodate combination results in a raster which identifies wetland-land-water conversions, such that water-toland is -6 , wetland-to-land is -4 , water-to-wetland is -2 , wetland-to-water equals 2 , land-to-wetland is 4, and land-to-water is 6 (Douglas et al. 2017).

\section{Results}

Total wetland area during the study period varied from 123.90 (26/Oct/2014) to $135.54 \mathrm{~km}^{2}$ (25/Apr/2011) and total land area varied from 156.96 (1/Apr/2014) to $169.05 \mathrm{~km}^{2}$ (17/Apr/1985). Between April 1985 and April 2017, there was a net wetland loss of $7.31 \mathrm{~km}^{2}$, or about $5.6 \%$ of the 1985 wetland area. During the same period, there was a net land-area loss of
$10.85 \mathrm{~km}^{2}$, or about $6.4 \%$ of the 1985 land area (Table 2).

Classification accuracy

An accuracy assessment of the reclassified binary wetland data from April 1989, October 1989, November 2005, March 2009, April 2011, and April 2013 was performed with 195 points. When compared with high-resolution aerial imagery, the overall accuracy ranged from $86.6 \%$ (28/Apr/1989) to $92 \%$ (25/Apr/ 2011) (Tables 3, S2). In comparison, Anderson et al. (1976) recommended a minimum accuracy for a classification system derived from remotely sensed data of $85 \%$, and the overall accuracy for the NOAA C-CAP (Coastal Change Analysis Program) landcover classification is $82.3 \%$ (NOAA 2012).

The user's accuracy (Table 3) measures errors of commission, represented by the inclusion of nonwetland reference pixels in the total wetland class. Most errors of commission occurred when small tidal creeks or ponds that cannot be resolved using 30-m resolution Landsat imagery were misclassified with

Table 2 Landsat image-acquisition dates and land-cover extents in square kilometers $\left(\mathrm{km}^{2}\right)$ used in this study

\begin{tabular}{|c|c|c|c|c|}
\hline Acquisition date & Total wetland $\left(\mathrm{km}^{2}\right)$ & Non-wetland land area $\left(\mathrm{km}^{2}\right)$ & Total land area $\left(\mathrm{km}^{2}\right)$ & Water $\left(\mathrm{km}^{2}\right)$ \\
\hline 24/Nov/1984 & 127.41 & 39.69 & 167.09 & 866.87 \\
\hline 17/Apr/1985 & 131.27 & 37.78 & 169.05 & 864.91 \\
\hline 28/Apr/1989 & 133.10 & 31.79 & 164.89 & 869.08 \\
\hline 05/Oct/1989 & 130.23 & 36.56 & 166.79 & 867.18 \\
\hline 26/Apr/1994 & 132.14 & 34.60 & 166.73 & 867.23 \\
\hline 04/Nov/1994 & 129.34 & 38.25 & 167.58 & 866.38 \\
\hline 18/Nov/1999 & 132.69 & 36.29 & 168.98 & 864.98 \\
\hline 05/Apr/2004 & 131.29 & 32.21 & 163.50 & 870.47 \\
\hline 02/Nov/2005 & 131.61 & 35.83 & 167.43 & 866.53 \\
\hline 16/May/2007 & 130.02 & 38.62 & 168.64 & 865.32 \\
\hline 16/Apr/2008 & 127.92 & 35.89 & 163.81 & 870.16 \\
\hline 26/Nov/2008 & 132.84 & 34.19 & 167.03 & 866.93 \\
\hline 18/Mar/2009 & 134.34 & 32.23 & 166.57 & 867.39 \\
\hline 25/Apr/2011 & 135.54 & 33.09 & 168.63 & 865.33 \\
\hline 14/Apr/2013 & 125.11 & 31.86 & 156.98 & 876.99 \\
\hline 01/Apr/2014 & 126.42 & 30.54 & 156.96 & 877.01 \\
\hline 26/Oct/2014 & 123.90 & 33.62 & 157.53 & 876.44 \\
\hline 22/May/2015 & 123.91 & 36.86 & 160.78 & 873.19 \\
\hline 04/09/2017 & 123.96 & 34.23 & 158.20 & 874.72 \\
\hline
\end{tabular}


Table 3 Wetland classification accuracy assessment results and reference datasets

\begin{tabular}{|c|c|c|c|c|c|}
\hline Date & Land cover & Users accuracy $(\%)$ & Producers accuracy $(\%)$ & Overall accuracy $(\%)$ & Reference dataset \\
\hline \multirow[t]{2}{*}{ 28/Apr/1989 } & Wetland & 81.1 & 94.5 & 86.6 & DOQQ (4/12/89) \\
\hline & Non-wetland classes & 92.5 & 82.0 & & \\
\hline \multirow[t]{2}{*}{ 05/Oct/1989 } & Wetland & 84.0 & 90.3 & 87.1 & DOQQ (4/12/89) \\
\hline & Non-wetland classes & 90.5 & 84.3 & & \\
\hline \multirow[t]{2}{*}{ 02/Nov/2005 } & Wetland & 85.3 & 93.3 & 91.3 & NAIP (2005) \\
\hline & Non-wetland classes & 95.5 & 90.0 & & \\
\hline \multirow[t]{2}{*}{ 18/Mar/2009 } & Wetland & 78.8 & 95.3 & 86.6 & NAIP (2009) \\
\hline & Non-wetland classes & 95.6 & 79.8 & & \\
\hline \multirow[t]{2}{*}{ 25/Apr/2011 } & Wetland & 86.5 & 84.9 & 92.0 & NAIP (2011) \\
\hline & Non-wetland classes & 94.4 & 95.1 & & \\
\hline \multirow[t]{2}{*}{ 25/Apr/2011 } & Wetland & 90.4 & 82.5 & 86.2 & NLCD (2011) \\
\hline & Non-wetland classes & 82.2 & 90.2 & & \\
\hline \multirow[t]{2}{*}{ 14/Apr/2013 } & Wetland & 75.7 & 97.4 & 87.2 & NAIP (9/2013) \\
\hline & Non-wetland classes & 97.9 & 79.6 & & \\
\hline
\end{tabular}

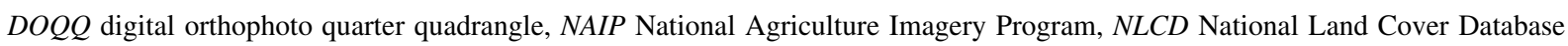

the surrounding wetlands. Water-level differences between Landsat image acquisition and aerial photography acquisition may also contribute to some errors of commission. The National Agriculture Imagery Program (NAIP) aerial photographs that were used to ground truth the land-cover classification data were typically acquired during the summer months, rather than spring or fall, and were acquired over periods ranging from days to months. The producer's accuracy measures errors of omission, which occur when cells classified as total wetland are represented by a nonwetland reference pixel. Comparison of the April 2011 reclassified wetland data with 2011 NLCD data (Table S3) indicates that errors of omission occurred when wetlands were misclassified as water or forested non-wetland land-cover classes.

Water-level trends

The rate of SLR derived using monthly mean sea-level data for the study period from 1980 to 2015 was $4.7 \mathrm{~mm} /$ year at the Lewes, DE tide gauge. This shows an acceleration in SLR rates over the study period compared with the long-term trend at Lewes (3.42 mm/year since 1919; NOAA 2018) but is consistent with published trends for the same period at Ocean City, MD (5.59 mm/year since 1975; NOAA 2018) and Wachapreague, VA (5.35 mm/year since
1978; NOAA 2018). Comparison of daily water-level data from Lewes and Wachapreague show regionallyelevated water levels caused by storm events, including Hurricane Sandy (Table S4).

No long-term tide gauges are located on the backbarrier shoreline of Assateague Island or the mainland estuarine shoreline in Chincoteague Bay. Tidal ranges are similar at the Lewes (located near the mouth of Delaware Bay) and Wachapreague (located along a tidal channel behind Parramore Island) gauges. Tide gauges at Ocean City Inlet (located about $1 \mathrm{~km}$ north of the study area on the back-barrier shoreline of Fenwick Island) and in Chincoteague Bay, however, show significantly reduced tidal ranges (Table S5; NOAA 2018). Additionally, tidal-stage data from the Chincoteague Bay stations show a tidal-cycle phase lag of several hours relative to the open-ocean gauges (Table S6).

\section{Wetland-change trends}

The relationship between land-cover extents and water levels at the time of image acquisition was tested using linear regression and Spearman rank correlation analyses (Tables S7, S8, S9). Because of the observed phase lag between open-ocean and estuarine tidal cycles, wetland and land areas were compared to water levels at multiple locations. For the South Point, 
Public Landing, Buntings Bridge, Jesters Island, and USCG stations where long-term historical data is not available, predicted water levels were used. No consistent, statistically significant $(p<0.05)$ correlation was identified between wetland or land area and actual (Lewes and Wachapreague) or predicted (Chincoteague Bay) water levels.

ANOVA analyses tested whether seasonality (spring or fall) affected the land-cover classifications (Table S6). No statistically significant $(p<0.05)$ differences exist between the spring and fall landcover distributions described in this study except for the forested land-cover class $(p=0.004)$. Comparisons between pre-storm (1984-2011) and post-storm (2013-2017) land-cover extents show an overall decrease in wetland and land area. ANOVA results for pre- and post-Hurricane Sandy extents (Table 4) indicate a significant $(p<0.01)$ decrease in total land, total wetland, and total marsh areas. Between October 1984 and April 2011, total land area averaged $166.91 \pm 1.78 \mathrm{~km}^{2}$, total wetland area averaged $131.41 \pm 2.30 \mathrm{~km}^{2}$, and total marsh area averaged $106.85 \pm 2.72 \mathrm{~km}^{2}$. Between April 2013 and April 2017 , total land, total wetland, and total marsh area averaged $158.09 \pm 1.59 \mathrm{~km}^{2}, \quad 124.66 \pm 1.11 \mathrm{~km}^{2}$, and $96.89 \pm 2.14 \mathrm{~km}^{2}$, respectively. From 1984 to 2011 , linear regression analyses show that total marsh, total wetland, and total land area was nearly stable (Table 5, Figs. 2, S1). When the post-Hurricane Sandy image dates are considered, the trends become negative for total marsh $\left(-0.31 \mathrm{~km}^{2} /\right.$ year, $\left.p<0.01\right)$ total wetland $\left(-0.13 \mathrm{~km}^{2} /\right.$ year, $\left.p=0.11\right)$ and total land $\left(-0.25 \mathrm{~km}^{2} /\right.$ year, $\left.p=0.01\right)$, however, only the total marsh and total land area trends are significant.
Chincoteague Bay estuarine wetlands

Similar to the results for the entire study area, landcover extents for the estuarine wetlands surrounding Chincoteague Bay (Table 6) were not significantly correlated with water levels (Tables S10, S11), and ANOVA results indicate significant $(p<0.01)$ decreases in post-Hurricane Sandy total land, total wetland, and total marsh areas (Table 7). Linear regression analysis (Table 8) show that land and wetland areas were decreasing $(p<0.05)$ within this analyses extent even prior to the passage of Hurricanes Irene and Sandy; wetland- and land-loss rates nearly doubled when the post-hurricane images are included (Figs. 3, S2).

\section{Wallops to Metompkin Islands}

Considering just the estuarine and mainland wetlands south of Chincoteague Bay (Table 9), total marsh, total wetland, and total land areas were significantly correlated $(p<0.01)$ with water levels at the Wachapreague tide gauge (Table S12). Comparisons between pre-storm (1984-2011) and post-storm (2013-2017) land-cover extents show significant $(p \leq 0.01)$ decreases in total land, total wetland, and total marsh extents and a concurrent increase in bare-earth land cover (Table 10) along this stretch of coastline. Linear regression trends (Table 11) show historical (1984-2011) increases $(p<0.05)$ in land and wetland areas (Figs. 4, S3) prior to the observed changes following the passage of Hurricanes Irene and Sandy.

Wetland persistence and land-cover switching

Prior to 2013, total wetland area remained relatively stable across the study area (Table 2). However, between 2011 and 2013, wetland losses increased
Table 4 Regression statistics for single-factor Analysis of Variance (ANOVA) analyses comparing pre- and postHurricane Sandy land-cover areas

\begin{tabular}{lccr}
\hline Land-cover class & $1984-2011$ average area $\left(\mathrm{km}^{2}\right)$ & 2013-2017 average area $\left(\mathrm{km}^{2}\right)$ & $p$ \\
\hline Total marsh & 106.85 & 96.89 & $<0.01$ \\
Mixed vegetation & 24.56 & 27.77 & 0.07 \\
Forested & 19.63 & 17.96 & 0.13 \\
Total bare earth & 15.88 & 15.46 & 0.61 \\
Total wetland & 131.41 & 124.66 & $<0.01$ \\
Total land & 166.91 & 158.08 & $<0.01$ \\
Water & 867.06 & 875.67 & $<0.01$ \\
\hline
\end{tabular}


Table 5 Land-cover change trends for pre- and post-Hurricane Sandy image acquisition dates

\begin{tabular}{lcccr}
\hline Land-cover class & Pre-sandy trend $\left(1984-2011, \mathrm{~km}^{2} /\right.$ year $)$ & $p$ & Overall trend $\left(1984-2017, \mathrm{~km}^{2} / \mathrm{year}\right)$ & $p$ \\
\hline Total marsh & -0.07 & 0.36 & -0.31 & $<0.01$ \\
Mixed vegetation & 0.17 & 0.09 & 0.18 & 0.01 \\
Forested & -0.03 & 0.55 & -0.06 & 0.16 \\
Total bare earth & -0.08 & 0.11 & -0.05 & 0.12 \\
Total wetland & 0.09 & 0.17 & -0.13 & 0.11 \\
Total land & -0.02 & 0.74 & -0.25 & 0.01 \\
Water & 0.02 & 0.74 & 0.24 & 0.01 \\
\hline
\end{tabular}
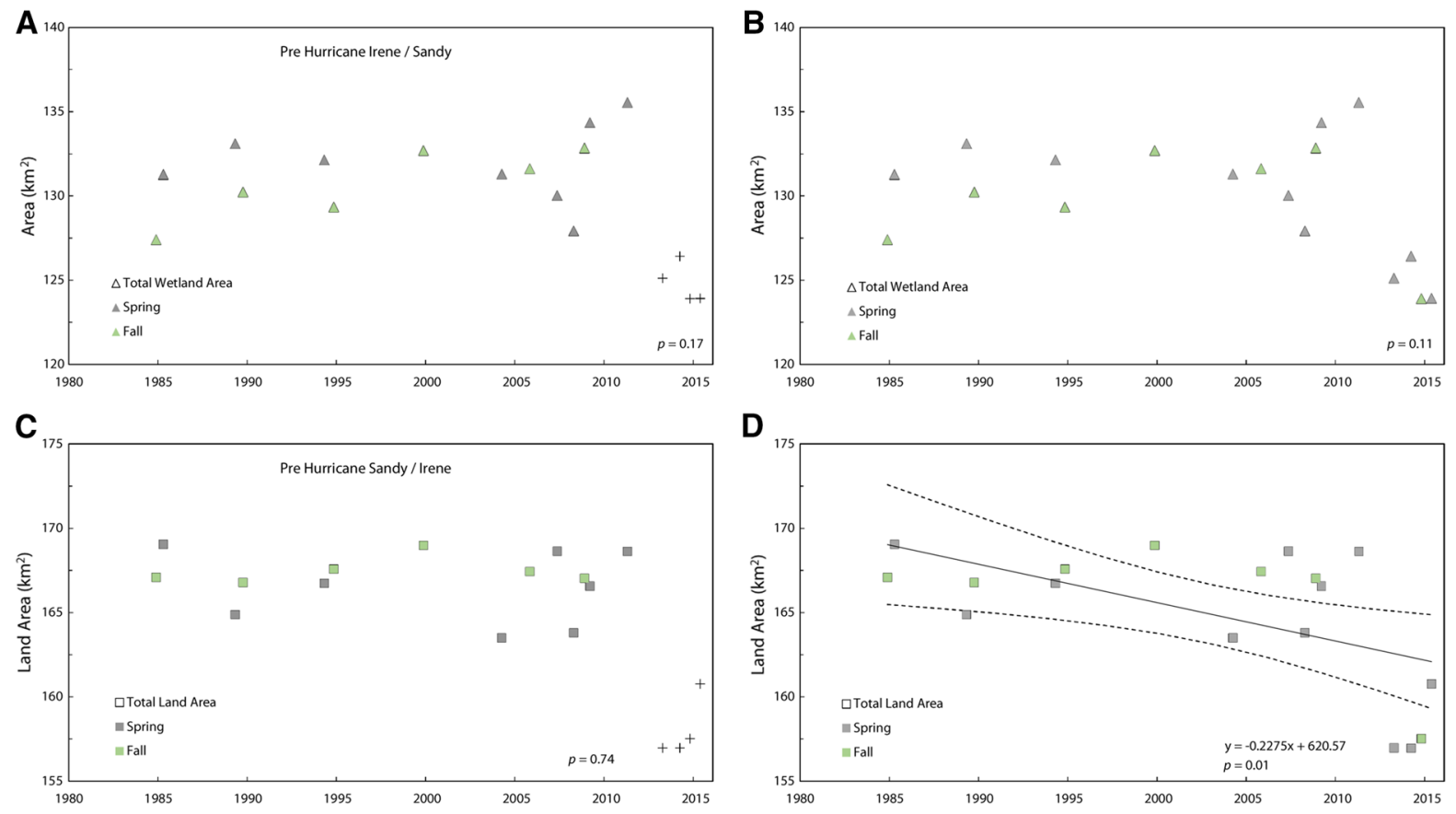

Fig. 2 Landsat-derived (a, b) total wetland and (c, d) total land area. Minimum wetland and land areas were observed in the 2013-2017 imagery after the passage of Hurricanes Irene (2011) and Sandy (2012). Significant decreases in wetland and total

land area (Table 5) were observed in the 2013-2017 imagery (b, d) after the passage of Hurricanes Irene (2011) and Sandy (2012)

significantly. The majority of the post-Hurricane Sandy wetland losses resulted from the conversion of wetlands to water (Table 12).

Wetland persistence (Fig. S4) and net wetland change were evaluated by converting the classified imagery to a simple binary classification. Prior to 2011 , total wetland area averaged $131.41 \mathrm{~km}^{2}$. For the period from 2013 to 2017 total wetland area averaged $124.66 \mathrm{~km}^{2}$ (Table 4). Between April 1985 and April 2017, $21.71 \mathrm{~km}^{2}$ of non-wetland land cover classes

switched to wetland. During the same period, $29.02 \mathrm{~km}^{2}$ of existing wetlands land cover classes switched to non-wetlands. The net change in wetland area equates to a net loss of $7.31 \mathrm{~km}^{2}$.

\section{Discussion}

Errors and uncertainties affecting land-cover change analyses stem from classification errors associated 
Table 6 Landsat image-acquisition dates and land-cover extents in square kilometers $\left(\mathrm{km}^{2}\right)$ for the estuarine wetlands surrounding Chincoteague Bay

\begin{tabular}{|c|c|c|c|c|}
\hline Acquisition date & Total wetland $\left(\mathrm{km}^{2}\right)$ & Non-wetland land area $\left(\mathrm{km}^{2}\right)$ & Total land area $\left(\mathrm{km}^{2}\right)$ & Water $\left(\mathrm{km}^{2}\right)$ \\
\hline 24/Nov/1984 & 82.11 & 34.82 & 116.93 & 649.96 \\
\hline 17/Apr/1985 & 82.59 & 32.64 & 115.23 & 651.66 \\
\hline 28/Apr/1989 & 82.63 & 28.60 & 111.24 & 655.65 \\
\hline 05/Oct/1989 & 82.48 & 31.58 & 114.07 & 652.82 \\
\hline 26/Apr/1994 & 84.37 & 30.43 & 114.80 & 652.10 \\
\hline 04/Nov/1994 & 82.64 & 34.18 & 116.82 & 650.07 \\
\hline 18/Nov/1999 & 81.50 & 32.00 & 113.50 & 653.38 \\
\hline 05/Apr/2004 & 79.93 & 29.30 & 109.23 & 657.66 \\
\hline 02/Nov/2005 & 82.14 & 31.61 & 113.75 & 653.14 \\
\hline 16/May/2007 & 80.19 & 32.64 & 112.84 & 654.05 \\
\hline 16/Apr/2008 & 77.01 & 32.18 & 109.19 & 657.70 \\
\hline 26/Nov/2008 & 81.42 & 30.96 & 112.38 & 654.51 \\
\hline 18/Mar/2009 & 82.86 & 29.01 & 111.87 & 655.02 \\
\hline 25/Apr/2011 & 83.21 & 29.55 & 112.77 & 654.12 \\
\hline 14/Apr/2013 & 77.86 & 27.83 & 105.69 & 661.20 \\
\hline 01/Apr/2014 & 80.38 & 27.06 & 107.44 & 659.45 \\
\hline 26/Oct/2014 & 78.47 & 28.89 & 107.36 & 659.53 \\
\hline 22/May/2015 & 78.90 & 29.67 & 108.57 & 658.32 \\
\hline 04/09/2017 & 75.80 & 29.10 & 104.90 & 661.45 \\
\hline
\end{tabular}

Table 7 Regression statistics for single-factor Analysis of Variance (ANOVA) analyses comparing pre- and post-Hurricane Sandy land-cover areas for Chincoteague Bay estuarine wetlands

\begin{tabular}{|c|c|c|c|}
\hline Land-cover class & 1984-2011 average area $\left(\mathrm{km}^{2}\right)$ & 2013-2017 average area $\left(\mathrm{km}^{2}\right)$ & $p$ \\
\hline Total marsh & 62.45 & 56.95 & $<0.01$ \\
\hline Mixed vegetation & 19.34 & 21.33 & 0.14 \\
\hline Total bare earth & 13.87 & 12.81 & 0.13 \\
\hline Total wetland & 81.79 & 78.28 & $<0.01$ \\
\hline Total land & 113.19 & 106.79 & $<0.01$ \\
\hline Water & 653.70 & 659.99 & $<0.01$ \\
\hline
\end{tabular}

with changes in water levels that affect the instantaneous land-water boundary and seasonal to interannual variability in vegetation growth cycles. Both short-term (Bernier et al. 2006; Jensen et al. 1993) and seasonal water-level fluctuations can influence wetland- and water-area classifications. Regression analyses show no correlation between regional wetland or land area and water-level variations. If the wetlands south of Chincoteague Bay are considered separately from the rest of the study area, however, land-cover extents, including total marsh, total wetland, and total land, are significantly correlated with water levels at the Wachapreague tide gauge. While this suggests that classification of these wetlands is more sensitive to water-level variations, comparison of land-cover extents derived from images acquired under similar tidal conditions (e.g., 26/November/2008 and 09/April/2017; Fig. 4) show reductions in wetland areas consistent with the observed pre- and postHurricane Sandy differences derived using all 
Table 8 Land-cover change trends for pre- and post-Hurricane Sandy image acquisition dates for Chincoteague Bay estuarine wetlands

\begin{tabular}{lcccr}
\hline Land-cover class & Pre-sandy trend $\left(1984-2011, \mathrm{~km}^{2} / \mathrm{year}\right)$ & $p$ & Overall trend $\left(1984-2017, \mathrm{~km}^{2} /\right.$ year $)$ & $p$ \\
\hline Total marsh & -0.17 & 0.02 & -0.25 & $<0.01$ \\
Mixed vegetation & 0.10 & 0.19 & 0.11 & 0.05 \\
Total bare earth & -0.07 & 0.06 & -0.07 & 0.01 \\
Total wetland & -0.07 & 0.17 & -0.14 & $<0.01$ \\
Total land & -0.15 & 0.02 & -0.26 & $<0.01$ \\
Water & 0.15 & 0.02 & 0.26 & $<0.01$ \\
\hline
\end{tabular}

A
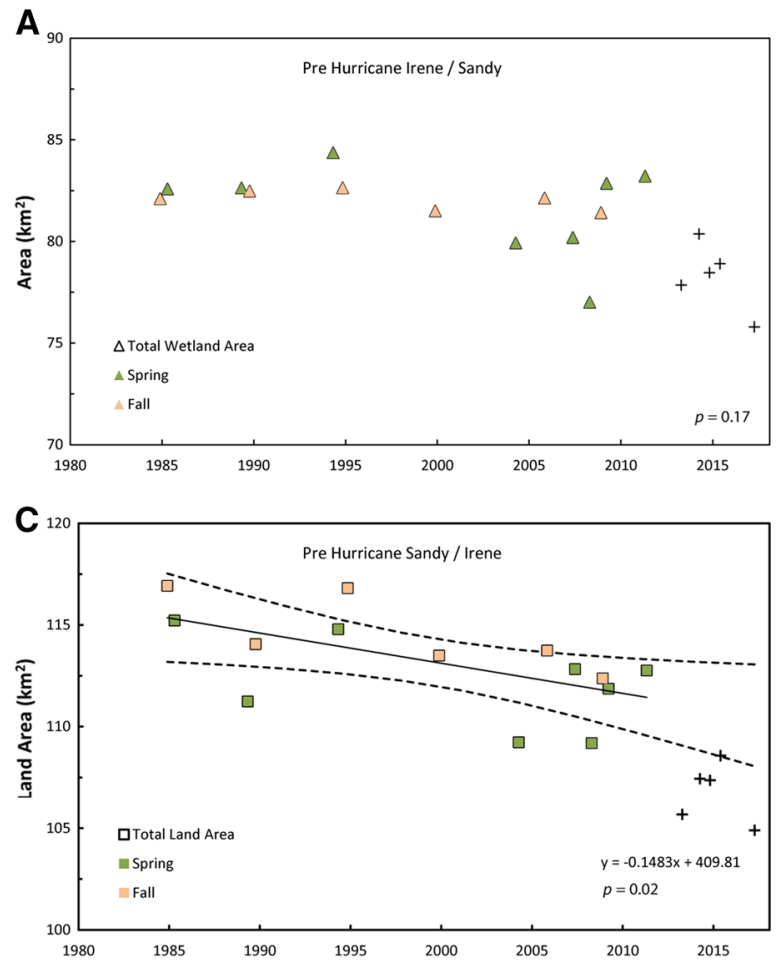

Fig. 3 Landsat-derived (a, b) total wetland and (c, d) total land area for the Chincoteague Bay estuarine analyses extent. Historical (1984-2011) data indicate that wetland and total land area was decreasing (a, c) even prior to the passage of

datasets. Quantifying the complex response of wetland area to varying water levels is complicated because the back-barrier and estuarine mainland wetlands along Chincoteague Bay experience reduced water-level variations and a phase lag compared with wetlands along the ocean-facing coastline south of Wallops Island (Tables S5, S7). Modeling results by Beudin et al. (2017) showed a highly reduced tidal range within Chincoteague Bay compared to Ocean City and
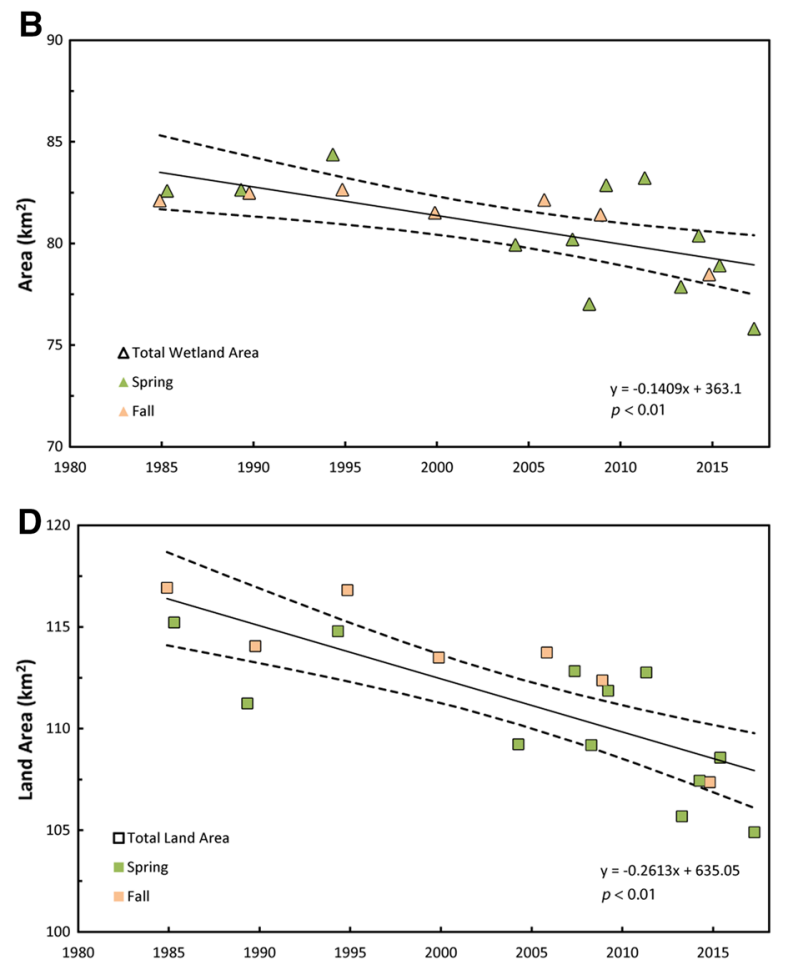

Hurricanes Irene (2011) and Sandy (2012); wetland- and landloss rates nearly doubled $(\mathbf{b}, \mathbf{d})$ when the post-hurricane images are included. Significant decreases in wetland and total land areas (Table 8) were observed in the 2013-2017 imagery

Chincoteague Inlets, but also predicted that there was significant spatial variability of maximum water levels within Chincoteague Bay during Hurricane Sandy in response to local wind and wave conditions. Thus, the resulting duration of flooding or inundation of adjacent estuarine wetlands was also highly variable.

Seasonally averaged water levels at the Lewes, DE tide gauge are highest during the summer and fall (Fig. S5). Consequently, analysis of wetland extents 
Table 9 Landsat image-acquisition dates and land-cover extents in square kilometers $\left(\mathrm{km}^{2}\right)$ for the estuarine wetlands south of Chincoteague Bay (Wallops to Metompkin Islands)

\begin{tabular}{|c|c|c|c|c|}
\hline Acquisition date & Total wetland $\left(\mathrm{km}^{2}\right)$ & Non-wetland land area $\left(\mathrm{km}^{2}\right)$ & Total land area $\left(\mathrm{km}^{2}\right)$ & Water $\left(\mathrm{km}^{2}\right)$ \\
\hline 24/Nov/1984 & 45.30 & 4.87 & 50.17 & 216.91 \\
\hline 17/Apr/1985 & 48.68 & 5.14 & 53.83 & 213.25 \\
\hline 28/Apr/1989 & 50.47 & 3.19 & 53.65 & 213.43 \\
\hline 05/Oct/1989 & 47.75 & 4.97 & 52.72 & 214.35 \\
\hline 26/Apr/1994 & 47.77 & 4.17 & 51.94 & 215.14 \\
\hline 04/Nov/1994 & 46.70 & 4.07 & 50.76 & 216.31 \\
\hline 18/Nov/1999 & 51.19 & 4.29 & 55.48 & 211.60 \\
\hline 05/Apr/2004 & 51.36 & 2.91 & 54.27 & 212.81 \\
\hline 02/Nov/2005 & 49.47 & 4.21 & 53.68 & 213.39 \\
\hline 16/May/2007 & 49.83 & 5.98 & 55.80 & 211.27 \\
\hline 16/Apr/2008 & 50.91 & 3.71 & 54.62 & 212.46 \\
\hline 26/Nov/2008 & 51.42 & 3.23 & 54.65 & 212.43 \\
\hline 18/Mar/2009 & 51.48 & 3.22 & 54.70 & 212.37 \\
\hline 25/Apr/2011 & 52.32 & 3.54 & 55.86 & 211.22 \\
\hline 14/Apr/2013 & 47.25 & 4.04 & 51.29 & 215.79 \\
\hline 01/Apr/2014 & 46.05 & 3.47 & 49.52 & 217.56 \\
\hline 26/Oct/2014 & 45.43 & 4.74 & 50.17 & 216.91 \\
\hline 22/May/2015 & 45.01 & 7.19 & 52.20 & 214.88 \\
\hline 04/09/2017 & 48.17 & 5.13 & 53.30 & 213.27 \\
\hline
\end{tabular}

Table 10 Regression statistics for single-factor Analysis of Variance (ANOVA) analyses comparing pre- and post-Hurricane Sandy land-cover areas for the southern part of the study area (Wallops to Metompkin Islands)

\begin{tabular}{lcrr}
\hline Land-cover class & $1984-2011$ average area $\left(\mathrm{km}^{2}\right)$ & 2013-2017 average area $\left(\mathrm{km}^{2}\right)$ & $p$ \\
\hline Total marsh & 44.40 & 39.95 & $<0.01$ \\
Mixed vegetation & 5.22 & 6.44 & 0.03 \\
Total bare earth & 2.00 & 2.65 & $<0.01$ \\
Total wetland & 49.62 & 46.38 & 0.01 \\
Total land & 53.72 & 51.30 & 0.01 \\
Water & 213.35 & 215.68 & 0.02 \\
\hline
\end{tabular}

derived from imagery collected during the fall months might be expected to show a relative decrease in wetland area that is not true wetland loss, but rather a response to seasonal flooding. Although no significant differences between spring and fall wetland areas were observed in this study (Table S6), higher average water levels during the summer and fall coincide with tropical storm season. Thus, waves and storm surge generated during tropical storms, coupled with SLR and this seasonal signal, will likely have greater impacts to coastal wetlands in the future (Barbosa et al. 2007; Barbosa and Silva 2009; Wahl et al. 2014).

Compared with high-resolution ( 0.5 to $2-\mathrm{m}$ pixel size) aerial imagery, analysis of $30-\mathrm{m}$ resolution Landsat imagery using the methods applied in this study cannot resolve changes that occur along the edges of interior ponds and tidal creeks or measure marsh-edge erosion that occurs at rates of a tens of centimeters to a few meters per year (e.g., McLoughlin et al. 2015; Priestas et al. 2015), although subpixel 
Table 11 Land-cover change trends for pre- and post-Hurricane Sandy image acquisition dates for the southern part of the study area (Wallops to Metompkin Islands)

\begin{tabular}{lcccr}
\hline Land-cover class & Pre-sandy trend (1984-2011, $\mathrm{km}^{2} /$ year $)$ & $p$ & Overall trend $\left(1984-2017, \mathrm{~km}^{2} / \mathrm{year}\right)$ & $p$ \\
\hline Total marsh & 0.10 & 0.03 & -0.06 & 0.27 \\
Mixed vegetation & 0.07 & 0.01 & 0.07 & 0.01 \\
Total bare earth & 0.00 & 0.88 & 0.02 & 0.08 \\
Total wetland & 0.17 & $<0.01$ & 0.01 & 0.88 \\
Total land & 0.13 & $<0.01$ & 0.01 & 0.81 \\
Water & -0.13 & $<0.01$ & -0.01 & 0.76 \\
\hline
\end{tabular}

A

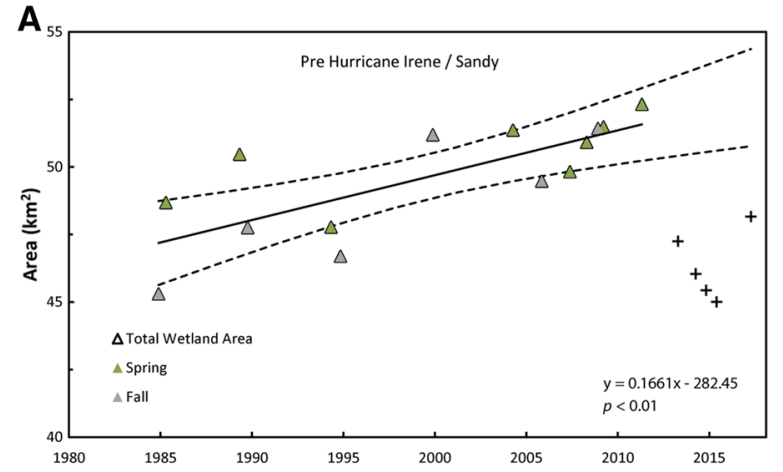

C

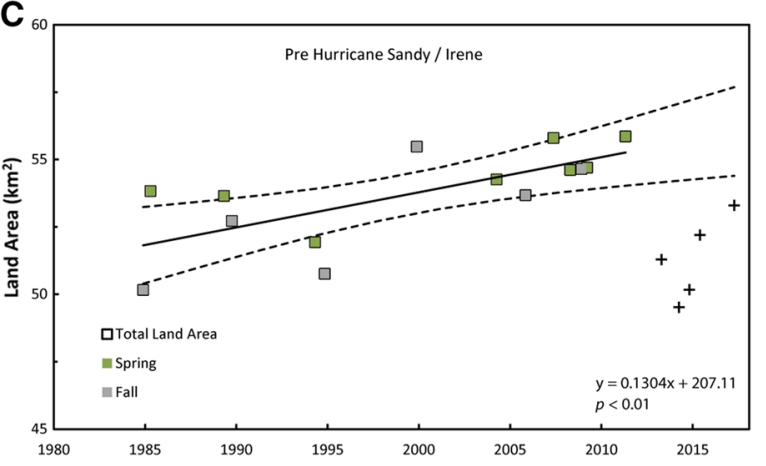

Fig. 4 Landsat-derived (a, b) total wetland and (c, d) total land area for the southern part of the study area (Wallops to Metompkin Islands). Significant decreases in wetland and total

techniques (e.g., Garcia-Rubio et al. 2015; Sethre et al. 2005) can significantly improve the resolution of shoreline or land-cover boundary detection. The strength of using an objective, unsupervised classification methodology with a consistent multispectral dataset is the ability to process more images, thus providing more data, than more time-consuming, supervised classification methodologies (Ozesmi and Bauer 2002). With historical satellite data, groundtruth or ancillary data used to guide the supervised
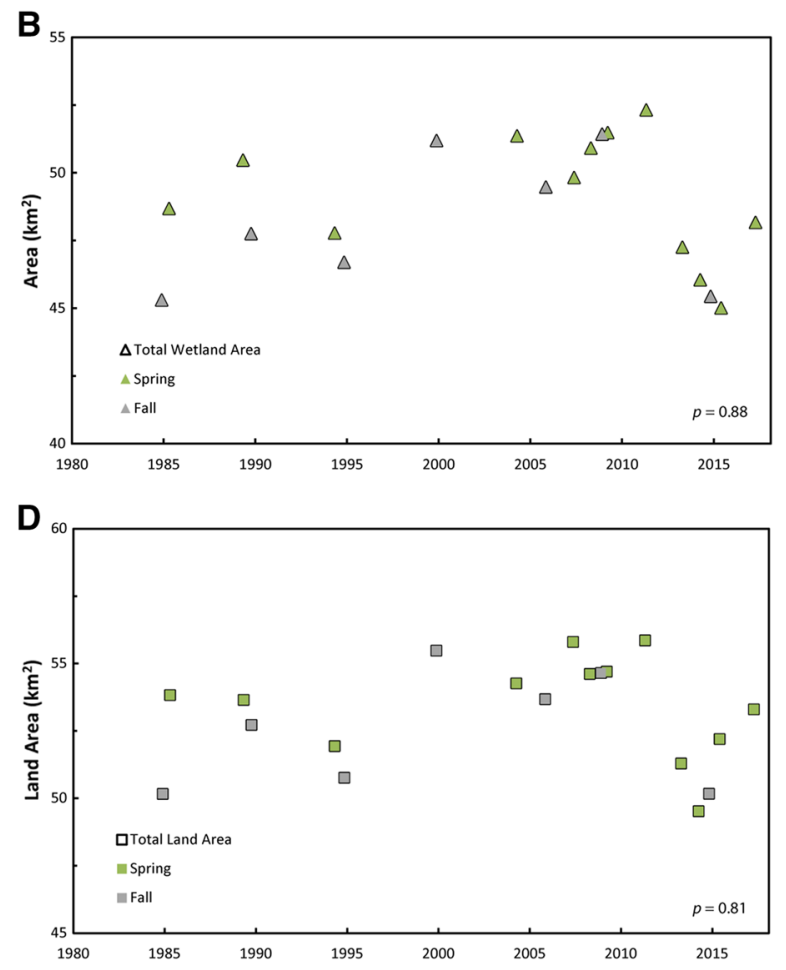

land area (Table 11) were observed in the 2013-2017 imagery (b, d) after the passage of Hurricanes Irene (2011) and Sandy (2012)

classification may not be available for all datasets. Additionally, high-resolution aerial imagery (a) is typically acquired at a much coarser temporal resolution (biennial to decadal), (b) may be acquired over several days to weeks and variable water-level conditions when considering large, regional areas, and (c) often require time-intensive hand digitization of desired features. The use of multiple image acquisition dates support regression analyses that simultaneously identify outlier data points, trends, and statistically 
Table 12 Land-cover switching and net wetland change for successive spring image-acquisition dates for the time period from April 1985 to April 2017, in square kilometers $\left(\mathrm{km}^{2}\right)$

\begin{tabular}{|c|c|c|c|c|c|c|c|}
\hline $\begin{array}{l}\text { Change } \\
\text { assessment }\end{array}$ & $\begin{array}{l}\text { Not wetland to } \\
\text { water }\end{array}$ & $\begin{array}{l}\text { Not wetland to } \\
\text { wetland }\end{array}$ & $\begin{array}{l}\text { Wetland to } \\
\text { water }\end{array}$ & $\begin{array}{l}\text { Water to } \\
\text { wetland }\end{array}$ & $\begin{array}{l}\text { Wetland to not } \\
\text { wetland }\end{array}$ & $\begin{array}{l}\text { Water to not } \\
\text { wetland }\end{array}$ & $\begin{array}{l}\text { Total wetland } \\
\text { change }\end{array}$ \\
\hline 1985-1989 & 1.97 & 6.99 & 8.27 & 7.16 & 6.91 & 0.82 & -1.03 \\
\hline 1989-1994 & 3.32 & 8.83 & 8.92 & 10.07 & 8.06 & 2.13 & 1.92 \\
\hline 1994-1999 & 1.30 & 7.44 & 10.02 & 10.70 & 7.57 & 2.86 & 0.55 \\
\hline 1999-2004 & 2.86 & 5.80 & 9.02 & 5.49 & 3.68 & 0.91 & -1.41 \\
\hline 2004-2009 & 1.48 & 5.22 & 7.89 & 10.91 & 6.68 & 2.00 & 1.56 \\
\hline 2008-2013 & 2.36 & 6.71 & 16.83 & 7.30 & 4.90 & 1.83 & -7.72 \\
\hline 2013-2014 & 1.02 & 4.31 & 7.98 & 7.96 & 2.98 & 1.02 & 1.31 \\
\hline 2014-2015 & 0.23 & 4.41 & 8.08 & 10.03 & 8.86 & 2.11 & -2.50 \\
\hline 2015-2017 & 1.16 & 6.97 & 8.40 & 7.22 & 5.13 & 1.34 & 0.66 \\
\hline
\end{tabular}

Total analysis extent (Fig. 1) is $1033.96 \mathrm{~km}^{2}$, of which more than 80 percent is open water. Negative wetland change values indicate wetland loss

significant changes in wetland area. The regression approach quantifies its own estimation errors; thus, any data, regardless of classification methodology or image resolution, can be included in future assessments.

Storm-induced wetland change

Although the measured variability in total marsh and total wetland extents in part reflects uncertainty associated with defining each $30-\mathrm{m}$ pixel to a single land-cover class, comparisons between pre-storm (prior to 2011) and post-storm (after 2013) extents show a significant $(p<0.01)$ decrease in wetland area (Tables 4, 9, 10). Considering the entire study-area extent (Fig. 2), post-storm wetland areas were all less than the minimum 1984-2011 wetland area. Similar wetland losses were documented following Hurricanes Andrew, Katrina, and Rita (Guntenspergen et al. 1995; Morton and Barras 2011) along the Northern Gulf of Mexico and Hurricane Isabel in wetlands adjacent to Delaware Bay (Kearney and Riter 2011). After several growing seasons following those hurricanes, wetland area and health mostly rebounded to pre-hurricane levels (Chabreck and Palmisano 1973; Conner et al. 1989; Courtemanche et al. 1999; Steyer et al. 2010; Kearney and Riter 2011; Steyer et al. 2013). Following the 2011 and 2012 Atlantic storm seasons, however, wetland losses in the study area persisted and total wetland area had not recovered almost 5 years after Hurricane Sandy.
Between 1984 and 2011, total wetland $\left(0.17 \mathrm{~km}^{2} /\right.$ year, $p<0.01)$ and total land $\left(0.13 \mathrm{~km}^{2} /\right.$ year, $p<0.01)$ area from Wallops to Metompkin Islands increased slightly (Fig. 4), largely a result of some new mixed vegetation wetlands that formed between prograding sand spits on Wallops Island at Chincoteague Inlet (Fig. S3). In comparison, the data show that estuarine wetland areas surrounding Chincoteague Bay were nearly stable during the same period. The slightly negative trend for these wetlands (Table 8 ) is largely driven by the $16 /$ April/2008 data point (Fig. 3). The majority of wetland losses observed in the 2013-2017 imagery were from interior back-barrier and estuarine mainland marshes and resulted from the expansion of open-water bodies and tidal channels (Fig. S6) or the submergence of wet marsh areas. Some of the greatest losses occurred within the mainland estuarine wetlands adjacent to Johnson Bay (Fig. 5). Visual analysis of Landsat and aerial imagery show a network of artificial canals, indicating significant anthropogenic modification of these wetlands. Such modifications could lead to altered wetland hydrology (Mendelssohn and Seneca 1980; Mendelssohn et al. 1981), which may contribute to increased susceptibility to storm-induced erosion (e.g., Howes et al. 2010). South of Assawoman Island, storm-induced shoreline erosion and overwash resulted in net landward migration of the barrier beaches and burial of the back-barrier wetlands (Figs. 6, 7a). 


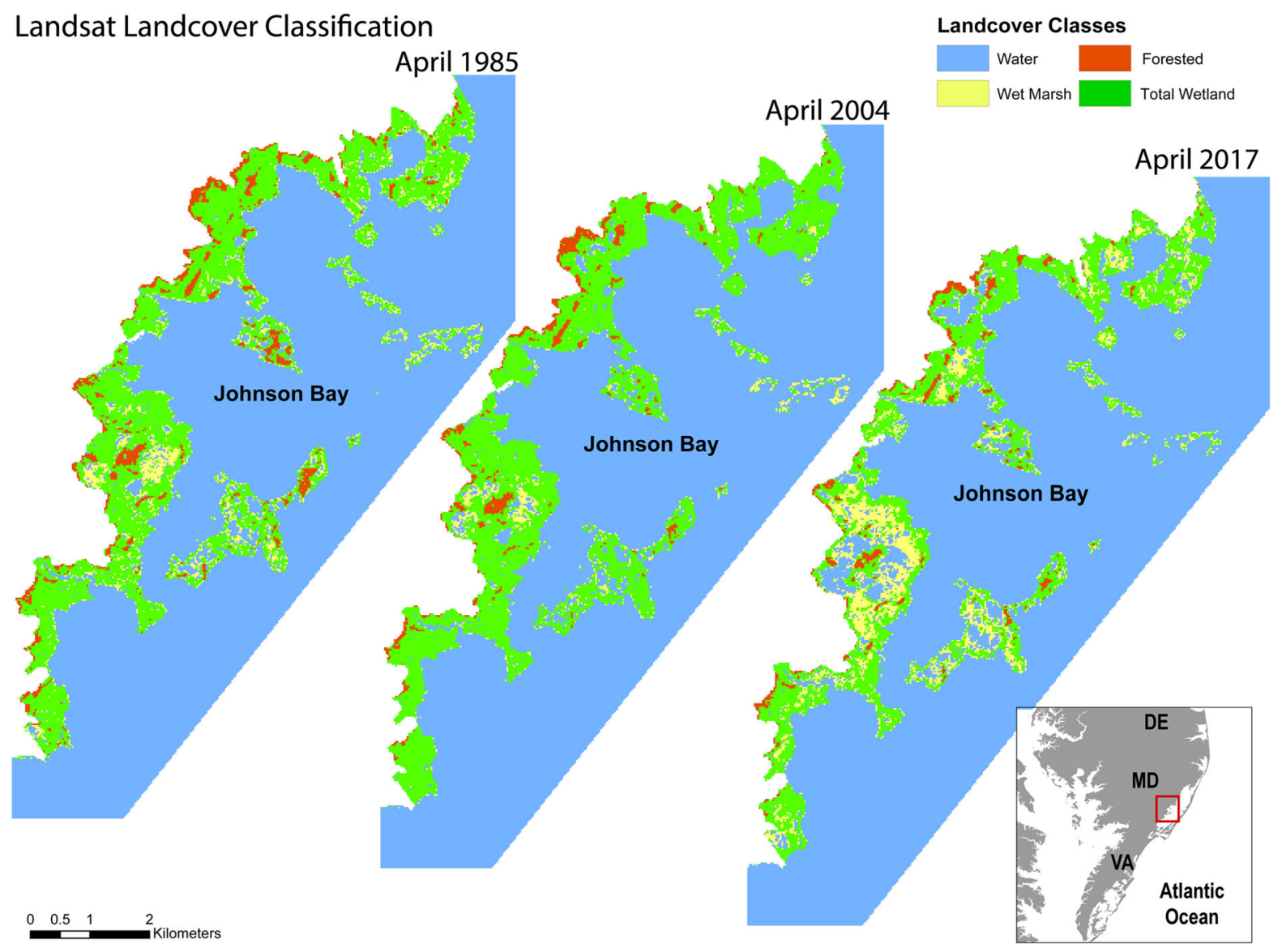

Fig. 5 a April 1985, b April 2004, and c April 2017 Landsatderived water, wet marsh, total wetland, and forested extents overlaid with the wet marsh land-cover class for estuarine wetlands adjacent to Johnson Bay. Some wetlands with

In coastal Louisiana, Morton et al. (2005) and Bernier et al. (2006) described wet marsh as an intermediate stage in the progression from emergent wetlands to open water. They observed that large extents of wet marsh were often visible in both Landsat and higher resolution color-infrared aerial imagery over a period of several years prior to complete submergence and conversion to open water at "hotspots" of subsidence-induced interior wetland loss. In this study, we observed some localized areas where expanses of wet marsh were common in the pre2011 imagery. In the post-storm imagery, some new or enlarged water features formed within the same wetlands where these "persistent" wet marsh areas occurred (Figs. 5, 7b). Although differentiation of "wet" marsh and marsh is based on visual interpretation of the multispectral image, the occurrence of persistent wet marsh extents in the 1985 to 2011 imagery converted to new or enlarged water bodies in the post-Hurricane Sandy imagery

interconnected wet marsh extents identifies areas that seem to be more sensitive to water-level variations. Thus, the presence of wet marsh in the study area may indicate interior wetlands that are more vulnerable to repeated storm impacts or submergence by future sealevel rise.

Historical storm impacts resulting in beach and dune erosion and overwash along the study area are well documented. Examples include extratropical systems in October 1991, January 1992, and December 1992 that eroded and overwashed beach and dune environments along northern Assateague Island (Schupp et al. 2013) as well as "twin" Nor'Easters that impacted the Atlantic coastline in January and February 1998. The 1998 storms generated offshore wave heights of more than $7 \mathrm{~m}$ (Sallenger et al. 1999), caused significantly elevated water levels (Table S4), 


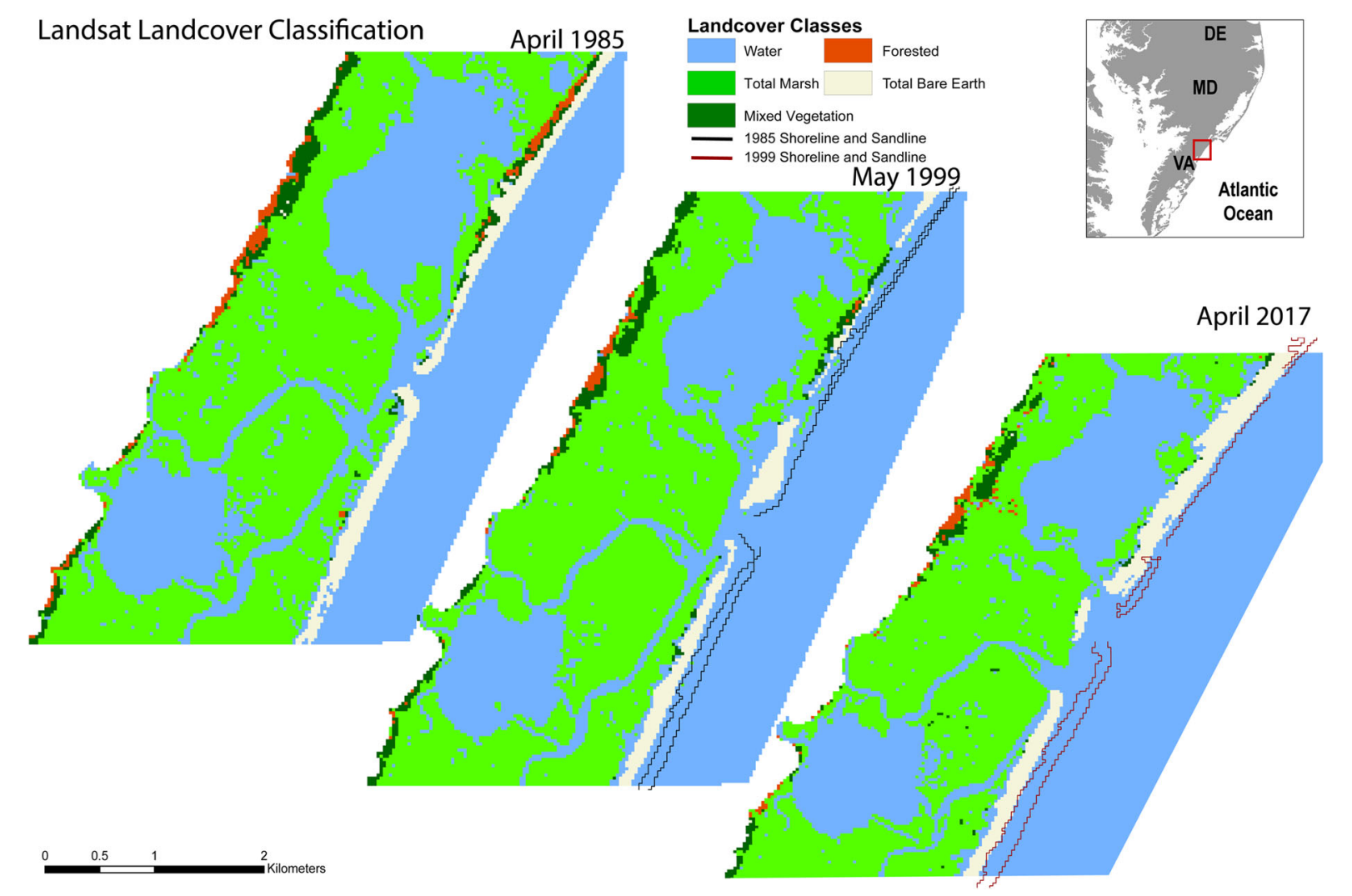

Fig. 6 a April 1985 and b May 1999, and c April 2017 Landsatderived water, total marsh, forested, mixed vegetation, and total bare earth land-cover classes with 1985 (b) and 1999 (c) sand extents (Bernier et al. 2015) for estuarine wetlands behind Assawoman and Metompkin Islands at the southern end of the

formed a large washover terrace extending across an approximately $2.5-\mathrm{km}$ long stretch of northern Assateague Island (Schupp et al. 2013), and resulted in extensive dune erosion and overwash along the length of Assateague Island (Sallenger et al. 1999) as well as along the Wallops, Assawoman, and Metompkin Island shorelines. Despite this, long-term trends indicate that both wetland area and total land area were relatively stable prior to the 2011-2012 storm seasons, and the consistent reductions in total wetland and land areas measured from 2013 to 2017 were not observed in earlier post-storm datasets.

Understanding how and where wetland changes occur is an important, but often ignored, component of coastal vulnerability assessments (Plant et al. 2018). Apparent short-term wetland losses and gains at landcover boundaries (e.g., wetland to water or water to wetland) are likely a result of misclassification of edge study area. Shoreline erosion and overwash following the January-February 1998 "twin" Nor 'Easters and the 2011-2012 storms resulted in net landward migration of the barrier beaches and burial of the former back-barrier wetlands

pixels, differences in estuarine water levels, or variability in vegetative growth at the time of image acquisition and did not affect the long-term trends. In comparison, significant interior wetland-to-water losses were observed within low lying wetlands in 2013. These post-Hurricane Sandy new water areas have persisted in the most recent imagery analyzed (2017). Comparisons of oblique aerial photographs (Morgan and Krohn 2014) taken before and after Hurricanes Irene and Sandy showing extensive flooding and wetland losses within formerly continuous back-barrier marshes and marsh islands support this conclusion (Fig. S8; Morgan 2015; Morgan and Krohn 2014; Subino et al. 2012). Minimal recovery of the formerly emergent wetland areas is evident in the subsequent imagery collected in 2014. Storm-induced wetland loss can result from the direct removal of vegetation, root mat, or surface sediment by storm 
Fig. 7 Wetland changes derived from satellite images acquired in 2008 and 2013 highlight differences observed in pre- and postHurricane Sandy imagery. a Assawoman and Metompkin Islands at the southern end of the study area. b Estuarine wetlands adjacent to Johnson Bay

\section{Wetland Change 2008-2013 \\ $\begin{array}{lll}0 & 2.5 & 5\end{array}$ 10 Kilometers}

Wetland Loss

Wetland Gain
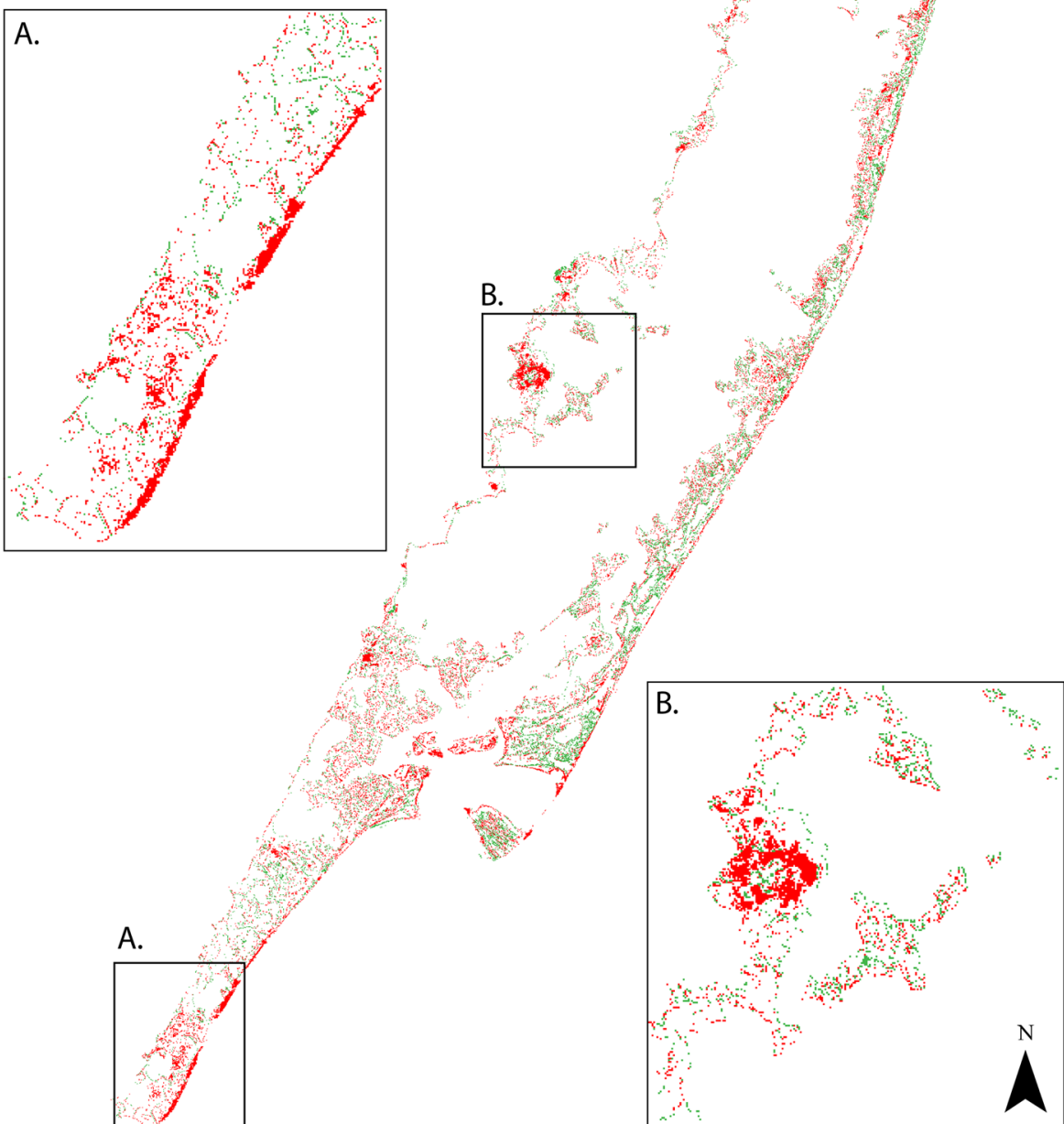

surge or wave action, burial by overwash, or prolonged flooding of the marsh surface (Morton and Barras 2011). Subsequent recovery of flooded or denuded marshes or re-vegetation of overwashed areas may take several growing seasons; additionally, Leonardi et al. (2018) noted that storm-formed ponds within wetland interiors may subsequently continue to enlarge even if the surrounding wetlands are able to aggrade at a sufficient rate relative to SLR. Thus, it is too soon to determine whether interior wetland losses observed in the 2013-2017 satellite imagery will be permanent or transitory.
At the southern end of the study area, however, it is likely that back-barrier wetland losses that resulted from burial by overwash and landward beach migration will be permanent. Historical shoreline-change trends along Assawoman and Metompkin Islands are highly erosional (Hapke et al. 2010). Comparison of shoreline positions and sand extents derived from Landsat imagery by Bernier et al. (2015) indicate that during periods of relatively infrequent or indirect storm impacts, this shoreline erosion results in net thinning of the barrier beaches with minimal changes to the back-barrier wetland extents. However, changes 
following the 1998 "twin" Nor "Easters included both shoreline erosion and overwash of the adjacent wetlands. By 2011, the buried wetlands remained bare sand and continued shoreline erosion resulted in beach thinning. Similar shoreline erosion and overwash with net landward beach migration was observed in the post-Hurricane Sandy Landsat imagery (Fig. 6).

The resilience of coastal wetlands to SLR depends on their ability to maintain elevation relative to MSL through vertical accretion or adapt by migrating landward. In many areas, inland migration is limited by topography, soils, hydrology, and land development. On Assateague Island, wetland migration is limited by a lack of upland (e.g., forested or shrub/ scrub) land area, and long-term shoreline-change trends indicate much of the estuarine and ocean-front shorelines are eroding (Hapke et al. 2010; Terrano and Smith 2015). Similarly, landward migration of the estuarine mainland wetlands and back-barrier wetlands behind Wallops, Assawoman, and Metompkin Islands in the southern part of the study area is limited because of extensive agricultural development of the adjacent coastal plains (Homer et al. 2007, 2015; Fry et al. 2011). Consequently, future persistence of these coastal wetlands will be largely dependent on whether vertical aggradation rates keep pace with SLR.

\section{Conclusions}

Wetland areas and wetland-change trends were markedly different before and after the landfall of Hurricanes Irene and Sandy in 2011 and 2012. During the three decades prior to Hurricane Sandy (1984-2011), there was no significant linear trend in total wetland or total marsh area. In comparison, when the 2013-2017 wetland areas were included, total marsh area showed a statistically significant negative trend $\left(-0.31 \mathrm{~km}^{2} /\right.$ year $)$. Differences between preand post-Hurricane Sandy wetland and land areas were significant $(p \leq 0.01)$ : the average post-Hurricane Sandy wetland area $\left(124.66 \mathrm{~km}^{2}\right)$ was more than $6 \mathrm{~km}^{2}$ less than the average pre-storm wetland area $\left(131.41 \mathrm{~km}^{2}\right)$. The conversion of marsh to water was the primary source of this storm-induced change.

Because there are limited options for upland migration of wetlands in the study area, the resilience of these estuarine mainland and barrier-island wetlands to future SLR and storm impact will depend on their ability to maintain elevation relative to MSL through accretion. Prior to the 2011 and 2012 storm seasons, observed wetland-area estimates suggest that marsh aggradation or migration processes, including establishment of new wetland areas adjacent to Chincoteague Inlet, were keeping pace with storm impacts and local SLR. Although erosion, overwash, and flooding during tropical and extratropical storms is common along the mid-Atlantic coast, the frequency of and response to storm impacts varied during the study period. Between 1991 and 1998, the study area was impacted by multiple extratropical systems, including systems in successive years (1991-1992) or within the same year (1998). Between 1999 and 2011 , only a few storm systems affected the region. In comparison, between August 2011 and October 2012, several storms impacted the region, including Hurricanes Irene (2011), Sandy (2012), and the Halloween Nor-Easter of 2011. We assume that Hurricane Sandy had the greatest impact due to the size and intensity of the storm and the resulting record high storm surge. However, the cumulative effects of multiple storms within a short time period likely contributed to the greater observed losses in coastal wetlands relative to earlier periods. Five years after Hurricane Sandy, wetland area had not significantly recovered, however more time may be necessary to assess if the observed wetland losses are permanent or if new growth within flooded marsh areas will be sufficient for the wetlands to recover to pre-storm extents. Comparisons of longterm and storm-driven wetland changes can lead to improved accuracy of habitat vulnerability models and greater understanding of potential impacts of future storms and SLR to coastal wetlands.

Open Access This article is distributed under the terms of the Creative Commons Attribution 4.0 International License (http:// creativecommons.org/licenses/by/4.0/), which permits unrestricted use, distribution, and reproduction in any medium, provided you give appropriate credit to the original author(s) and the source, provide a link to the Creative Commons license, and indicate if changes were made.

Funding This study was supported by the USGS Coastal and Marine Geology Program and Hurricane Sandy supplemental funding. 


\section{References}

Allen YC, Couvillion BR, Barras JA (2012) Using multitemporal remote sensing imagery and inundation measures to improve land change estimates in coastal wetlands. Estuar Coasts 35:190-200

Anderson JR, Hardy EE, Roach JT, Witmer RE (1976) A land use and land cover classification system for use with remote sensor data. U.S. Geological Survey Professional Paper 964

Avila LA, Cangialosi J (2011) Tropical cyclone report-Hurricane Irene. NOAA National Hurricane Center report AL092011

Barbier EB, Hacker SD, Kennedy C, Kock EW, Stier AC, Silliman BR (2011) The value of estuarine and coastal ecosystem services. Ecol Monogr 81(2):169-193

Barbosa SM, Silva ME (2009) Low-frequency sea-level change in Chesapeake Bay: changing seasonality and long-term trends. Estuar Coast Shelf Sci 83:30-38

Barbosa SM, Silva ME, Fernandes MJ (2007) Changing Seasonality in north Atlantic coastal sea level from the analysis of long tide gauge records. Tellus 60A:165-177

Barras J, Beville S, Britsch D, Hartley S, Hawes S, Johnston J, Kemp P, Kinler Q, Martucci A, Porthouse J, Reed D (2003) Historical and projected coastal Louisiana land changes: 1978-2050 (39p). United States Geological Survey.

Bernier JC, Morton RA, Barras JA (2006) Constraining rates and trends of historical wetland loss, Mississippi River Delta Plain, South-Central Louisiana. Coastal Environment and Water Quality, pp 371-382

Bernier JC, Douglas SH, Terrano JF, Barras JA, Plant NG, Smith CG (2015) Land-cover types, shoreline positions, and sand extents derived from Landsat satellite imagery, Assateague Island to Metompkin Island, Maryland and Virginia, 1984 to 2014. U.S. Geological Survey Data Series 968

Beudin A, Ganju NK, Define Z, Aretxabaleta AL (2017) Physical response of a back-barrier estuary to a post-tropical cyclone. J Geophys Res 122:5888-5904. https://doi. org/10.1002/2016jc012344

Blake ES, Kimberlain TB, Berg RJ, Cangialosi JP, Beven JL II (2013) Tropical cyclone report-Hurricane Sandy. NOAA National Hurricane Center report AL182012

Braatz S, Fortuna S, Broadhead J, Leslie R, (2007) Coastal protection in the aftermath of the Indian Ocean Tsunami. What role for forests and trees? In: Proceedings of the FAO Regional Technical Workshop. Khao Lak, Thailand, 28-31 August 2006

Braud DH Jr., Feng W (1998) Semi-automated construction of the Louisiana coastline digital land/water boundary using landsat thematic mapper satellite imagery. Department of Geography \& Anthropology, Louisiana State University. Louisiana Applied Oil Spill Research and Development Program, OSRAPD Technical Report Series 97-002

Brinson MM, Christian RR, Blum LK (1995) Multiple states in the sea-level induced transition from terrestrial forest to estuary. Estuaries 18(4):648-659

Cahoon DR (2006) A review of major storm impacts on coastal wetland elevations. Estuar Coasts 29(6A):889-898
Carruthers T, Beckert K, Dennison B, Thomas J, Saxby T, Williams M, Fischer T, Kumer J, Schupp C, Sturgis B, Zimmerman C (2011) Assateague Island National Seashore Natural Resources Condition Assessment, Maryland and Virginia. National Park Service Natural Resource Report NPS/ASIS/NRR-2011/405

Chabreck RH, Palmisano AW (1973) The effects of Hurricane Camille on the marshes of the Mississippi River delta. Ecology 54(5):1118-1123

Chander G, Markham BL, Helder DL (2009) Summary of current radiometric calibration coefficients for Landsat MSS, $\mathrm{TM}, \mathrm{ETM}+$, and EO-1 ALI sensors. Remote Sens Environ 113:893-903. https://doi.org/10.1016/j.rse.2009. 01.007

Chapman VJ (1960) Salt marshes and salt deserts of the world. Interscience, New York, p 392

Chavez PS Jr (1988) An improved dark-object subtraction technique for atmospheric scattering correction of multispectral data. Remote Sens Environ 24:459-479

Chavez PS Jr (1989) Radiometric calibration of Landsat Thematic Mapper multispectral images. Photogramm Eng Remote Sens 55(9):1285-1294

Chavez PS Jr (1996) Image-based atmospheric correctionsRevisited and improved. Photogramm Eng Remote Sens 62(9):1025-1036

Cochard R, Ranamukhaarachchi SL, Shivakotib GP, Shipin OV, Edwards PJ, Seeland KT (2008) The 2004 tsunami in Aceh and Southern Thailand: a review on coastal ecosystems, wave hazards and vulnerability. Perspect Plant Ecol Evol Syst 10:3-40

Conner WH, Day JW, Baumann RH, Randall JM (1989) Influence of hurricanes on coastal ecosystems along the northern Gulf of Mexico. Wetl Ecol Manage 1(1):45-56

Courtemanche RP Jr, Hester MW, Mendelssohn IA (1999) Recovery of a Louisiana barrier island marsh plant community following extensive hurricane-induced overwash. J Coast Res 15(4):872-883

Craft C, Clough J, Ehman J, Joye S, Park R, Pennings S, Guo H, Machmuller M (2009) Forecasting the effects of accelerated sea-level rise on tidal marsh ecosystem services. Front Ecol Environ 7(2):73-78

Crosby SC, Sax DF, Palmer ME, Booth HS, Deegan LA, Bertness MD, Leslie HM (2016) Salt marsh persistence is threatened by predicted sea-level rise. Estuar Coast Shelf Sci 181:93-99

Darwin RF, Tol RSJ (2001) Estimates of the economic effects of sea level rise. Environ Resour Econ 19:113-129

Day JW, Christian RR, Boesch DM, Yanez-Arancibia A, Morris J, Twilley RR, Naylor L, Schaffner L, Stevenson C (2008) Consequences of climate change on the ecogeomorphology of coastal wetlands. Estuar Coasts 31:477-491. https://doi. org/10.1007/s12237-008-9047-6

DeJong BD, Bierman PR, Newell WL, Rittenour TM, Mahan SA, Balco G, Rood DH (2015) Pleistocene relative sea levels in the Chesapeake Bay Region and their implications for the next century. GSA Today 25:4-10

DeLaune RD, Baumann RH, Gosselink JG (1983) Relationships among vertical accretion, coastal submergence, and erosion in a Louisiana gulf coast marsh. J Sedim Petrol 53(1):147-157 
DeLaune RD, Nyman JA, Patrick WH Jr. (1994) Peat collapse, ponding, and wetland loss in a rapidly submerging coastal marsh. J Coast Res 10(4):1021-1030

Donnelly JP, Bertness MD (2001) Rapid shoreward encroachment of salt marsh cordgrass in response to accelerated sealevel rise. Proc Natl Acad Sci USA 98(25):14218-14223

Douglas SD, Bernier JC, Smith KEL (2017) Wetland-change data derived from Landsat imagery, Assateague Island to Metompkin Island, Maryland and Virginia, 1984 to 2015: U.S. Geological Survey data release. https://doi.org/10. 5066/f76t0khh

Enwright NM, Griffith KT, Osland MJ (2016) Barriers to and opportunities for landward migration of coastal wetlands with sea-level rise. Front Ecol Environ 14(6):307-316. https://doi.org/10.1002/fee.1282

Erwin RM, Sanders GM, Prosser DJ (2004) Changes in lagoonal marsh morphology at selected northeastern Atlantic coast sites of significance to migratory waterbirds. Wetlands 14(4):891-903

Fickas KC, Choen WB, Yang Z (2016) Landsat-based monitoring of annual wetland change in the Williamette Valley of Oregon, USA from 1972 to 2012. Wetl Ecol Manag 24:73-92. https://doi.org/10.1007/s11273-015-9452-0

Fitzpatrick-Lins K (1981) Comparison of sampling procedures and data analysis for a land-use and land-cover map. Photogramm Eng Remote Sens 47:343-351

Frazier PS, Page KJ (2000) Water body detection and delineation with Landsat TM data. Photogram Eng Remote Sens 66(12):1461-1467

French J (2006) Tidal marsh sedimentation and resilience to environmental change-Exploratory modelling of tidal, sea-level and sediment supply forcing in predominantly allochthonous systems. Mar Geol 235(1-4):119-136

Fry J, Xian G, Jin S, Dewitz J, Homer C, Yang L, Barnes C, Herold N, Wickham J (2011) Completion of the 2006 National Land Cover Database for the Conterminous United States. Photogram Eng Remote Sens 77(9):858-864

Ganju NK, Defne Z, Kirwan ML, Fagherazzi S, D’Alpaos A, Carniello L (2017) Spaitally integrative metrics reveal hidden vulnerability of microtidal salt marshes. Nat Commun 8:14156. https://doi.org/10.1038/ncomms14156

García-Rubio G, Huntley D, Russell P (2015) Evaluating shoreline identification using optical satellite images. Mar Geol 359:96-105

Guntenspergen GR, Cahoon DR, Grace J, Steyer GD, Fournet S, Townson MA, Foote AL (1995) Impacts of Hurricane Andrew on the coastal zones of Florida and Louisiana: 22-26 August 1992. J Coast Res 21:324-339

Halpern BS, Walbridge S, Selkoe KA, Kappel CV, Micheli Fl, D'Agrosa C, Bruno JF, Casey KS, Ebert C, Fox HE, Fujita R, Heinemann D, Lenihan HS, Madin EMP, Perry MT, Selig ER, Spalding M, Steneck R, Watson R (2008) A global map of human impacts on marine ecosystems. Science 319:948-952

Hansen MC, Loveland TR (2012) A review of large area monitoring of land cover change using Landsat data. Remote Sens Environ 122:66-74

Hapke CJ, Himmelstoss EA, Kratzmann M, List JH, Thieler ER (2010) National assessment of shoreline change: Historical shoreline change along the New England and Mid-Atlantic coasts. U.S. Geological Survey Open-File Report 2010-1118, p 57

Homer C, Dewitz J, Fry J, Coan M, Hossain N, Larson C, Herold N, McKerrow A, VanDriel JN, Wickham J (2007) Completion of the 2001 National Land Cover Database for the Conterminous United States. Photogramm Eng Remote Sens 73(4):337-341

Homer C, Dewitz J, Yang L, Jin S, Danielson P, Xian G, Coulston J, Herold N, Wickham J, Megown K (2015) Completion of the 2011 National Land Cover Database for the Conterminous United States-representing a decade of land cover change information. Photogramm Eng Remote Sens 81(5):345-354

Howes NC, FitzGerland DM, Hughes ZJ, Georgiou IY, Kulp MA, Miner MD, Smith JM, Barras JA (2010) Hurricaneinduced failure of low salinity wetlands. PNAS 107(32):14014-14019. https://doi.org/10.1073/plans. 0914582107

Jankowski KL, Tornqvist TE, Fernandes AM (2017) Vulnerability of Louisiana's coastal wetlands to present-day rates of relative sea-level rise. Nat Commun 8:14792. https://doi. org/10.1038/ncomms 14792

Jensen JR, Ramsey EW III, Mackey HE, Christensen ES, Sharitz RR (1987) Inland wetland change detection using aircraft MSS data. Photogramm Eng Remote Sens 60(4):419-426

Jensen JR, Cowen DJ, Althausen JD (1993) The detection and prediction of sea level changes on coastal wetlands using satellite imagery and a geographic information system. Geocarto Int 8(4):87-98

Jin S, Yang L, Danielson P, Homer C, Fry J, Xian G (2013) A comprehensive change detection method for updating the National Land Cover Database to circa 2011. Remote Sens Environ 132:159-175

Kearney and Riter (2011) Itnter-annual variablity in delaware Bay Brackish marsh vegetation, USA. Wetl Ecol Manag 19:373-388

King SE, Lester JN (1995) The value of salt marsh as a sea defense. Mar Pollut Bull 30:180-189

Kirwan and Megonigal (2013) Tidal wetland stability in the face of human impacts and sea-level rise. Nature 504(7478):53

Koch EW, Barbier EB, Silliman BR, Reed DJ, Perillo GME, Hacker SD, Granek EF, Primavera JH, Muthiga N, Polasky S, Halpern BS, Kennedy CJ, Kappel CV, Wolanski E (2009) Non-linearity in ecosystem services: temporal and spatial variability in coastal protection. Front Ecol Environ 7:29-37

Kranz DE, Hobbs CH III, Wikel GL (2016) Atlantic coast and inner shelf. In: Bailey CM, Sherwood WC, Eaton LS, Powars DS The geology of Virginia, Virginia Museum of Natural History, Special Publication 18, p 538

Lee SY, Dunn RJK, Young RA, Connolly RM, Dale PER, Dehayr R, Lemckert CJ, McKinnon S, Powell B, Teasdale PR, Welsh DT (2006) Impact of urbanization on coastal wetland structure and function. Austral Ecol 31(2):149-163. https://doi.org/10.1111/j.1442-9993.2006. 01581.x

Leonardi N, Fagharazzi S (2014) How waves shape salt marshes. Geology 42(10):887-890. https://doi.org/10.1130/ G35751.1

Leonardi N, Ganju NK, Fagharazzi S (2016) A linear relationship between wave power and erosion determines salt- 
marsh resilience to violent storms and hurricanes. PNAS 113(1):64-68. https://doi.org/10.1073/pnas.1510095112

Leonardi N, Carnacina I, Donatelli C, Ganju NK, Plater AJ, Schuerch M, Temmerman S (2018) Dynamic interactions between coastal storms and salt marshes: a review. Geomorphology 301:92-107

Letzsch WS, Frey RW (1980) Deposition and erosion in a Holocene salt marsh, Sapelo Island, Georgia. J Sedim Petrol 50:529-542

Li Y, Zhu X, Sun X, Wang F (2009) Landscape effects of environmental impact on bay-area wetlands under rapid urban expansion and development policy: a case study of Lianyungang, China. Landsc Urban Plan 94:218-227. https://doi.org/10.1016/j.landurbplan.2009.10.006

Lotze HK, Lenihan HS, Bourque BJ, Bradbury RH, Cooke RG, Kay MC, Kidwell SM, Kirby MX, Peterson CH, Jackson JBC (2006) Depletion, degradation, and recovery potential of estuaries and coastal seas. Science 312:1806-1809

McKee KL, Cherry JA (2009) Hurricane Katrina sediment slowed elevation loss in subsiding Brackish marshes of the Mississippi River Delta. Wetlands 29(1):2-15

McLoughlin SM, Wiberg PL, Safak I, McGlathery KJ (2015) Rates and forcing of marsh edge erosion in a shallow coastal bay. Estuaries and Coasts 38(2):620-638

MEA (Millennium Ecosystem Assessment) (2005) Chapter 19, Coastal Systems. Ecosystems and human well-being: current state and trends. Island Press, Washington, D.C., USA, pp 513-550

Mendelssohn IA, Seneca ED (1980) The influence of soil drainage on the growth of salt marsh cordgrass Spartina alterniflora in North Carolina. Estuar Coast Mar Sci 11:27-40

Mendelssohn IA, McKee KL, Patrick WH (1981) Oxygen deficiency in Spartina alterniflora roots. Metabolic adaptation to anoxia. Science 214:439-441

Michener WK, Blood ER, Bildstein KL, Brinson MM, Gardner LR (1997) Climate change, hurricanes and tropical storms, and rising sea level in coastal wetlands. Ecol Adapt 7(3):770-801. https://doi.org/10.2307/2269434

Mitsch WJ, Gosselink JG (2000) Wetlands. Wiley, New York, p 600

Morgan KLM (2015) Baseline coastal oblique aerial photographs collected from the Virginia/North Carolina Border to Montauk Point, New York, October 5-6, 2014: U.S. Geological Survey Data Series 958. https://doi.org/10. 3133/ds958

Morgan KLM, Krohn MD (2014) Post-Hurricane Sandy coastal oblique aerial photographs collected from Cape Lookout, North Carolina, to Montauk, New York, November 4-6, 2012. U.S. Geological Survey Data Series 858

Morris JT, Sundareshwar PV, Nietch CT, Kjerfve B, Cahoon DR (2002) Responses of coastal wetlands to rising sea level. Ecology 83(10):2869-2877

Morton RA, Barras JA (2011) Hurricane impacts on coastal wetlands: a half-century record of storm-generated features from Southern Louisiana. J Coast Res 27(6A):27-43

Morton RA, Bernier JC, Barras JA, Ferina NF (2005) Rapid subsidence and historical wetland loss in the Mississippi delta plain: likely causes and future implications. U. S, Geological Survey
Munger S, Kraus NC (2010) Frequency of extreme storms based on beach erosion at Northern Assateague Island, Maryland. Shore Beach 78(2):3-10

National Oceanic and Atmospheric Administration (NOAA) (2012) Hurricane Sandy Advisory Number 29. NWS National Hurricane Center Bulletin ZCZC MIATCPAT3 ALL TTAA00 KNHC DDHHMM

National Oceanic and Atmospheric Administration (NOAA) (2014) Southeast 2010 coastal change analysis program accuracy assesement. Charelston, SC. Coastal Services Center. https://coast.noaa.gov/data/digitalcoast/pdf/ccapassessment-southeast.pdf

National Oceanic and Atmospheric Administration (NOAA) (2018) Center for Operational Oceanographic Products and Services (CO-OPS) Tides and Currents database, last Accessed May 2018 at http://tidesandcurrents.noaa.gov

Neumann B, Vafeidis AT, Zimmermann J, Nicholls RJ (2015) Future coastal population growth and exposure to sea-level rise and coastal flooding - a global assessment. PLoS ONE 10(3):e0118571

Nicholls RJ, Hoozemans FMJ, Marchand M (1999) Increasing flood risk and wetland losses due to global sea-level rise: regional and global analyses. Glob Environ Change 9:69-87

Ozesmi SL, Bauer ME (2002) Satellite remote sensing of wetlands. Wetl Ecol Manag 10:381-402

Pethick JS (1981) Long-term accretion rates on tidal salt marshes. J Sedim Petrol 51:571-577

Plant NG, Smith KEL, Passeri DL, Smith CG, Bernier JC (2018) Barrier-island and estuarine-wetland physical-change assessment after Hurricane Sandy. U.S. Geological Survey Open-File Report 2017-1157, p 36

Priestas AM, Mariotti G, Leonardi N, Fagherazzi S (2015) Coupled wave energy and erosion dynamics along a salt marsh boundary, Hog Island Bay, Virginia, USA. J Mar Sci Eng 3(3):1041-1065. https://doi.org/10.3390/ jmse3031041

Ramsey EW III, Laine SC (1997) Comparison of landsat thematic mapper and high resolution photography to identify change in complex coastal wetlands. J Coast Res 13(2):281-292

Roth D (2011) Storm Summary Number 8 for Autumn MidAtlantic to Northeast U.S. Major Winter Storm. Camp Springs, MD. Hydrometeorological Prediction Center. http://www.wpc.ncep.noaa.gov/winter_storm_summaries/ 2011/storm16/stormsum_8.html

Ryan S (2011) Storm Summary Number 9 for Autumn MidAtlantic to Northeast U.S. Major Winter Storm. Camp Springs, MD. Hydrometeorological Prediction Center. http://www.wpc.ncep.noaa.gov/winter_storm_summaries/ 2011/storm16/stormsum_9.html

Sallenger AH, Doran KS, Howd PA (2012) Hotspot of accelerated sea-level rise on the Atlantic coast of North America. Nat Clim Change 2:884-888

Sallenger AH Jr., Howd PA, Brock JC, Krabill WB, Swift R, Manizade S, Duffy M (1999) Scaling winter storm impacts on Assateague Island, Maryland, Virginia. In: Coastal sediments '99: proceedings of the 4th International Symposium on Coastal Engineering and Science of Coastal Sediment Processes, Hauppauge, New York, June 21-23, 1999, American Society of Civil Engineers, pp 1815-1825 
Schupp CA, Winn NT, Pearl TL, Kumer JP, Carruthers TJB, Zimmerman CS (2013) Restoration of overwash processes creates piping plover (Charadrius melodus) habitat on a barrier island (Assateague Island, Maryland). Estuar Coast Shelf Sci 116:11-20

Sethre PR, Rundquist BC, Todhunter PE (2005) Remote detection of prairie pothole ponds in the Devils Lake Basin, North Dakota. GIScience Remote Sens 42(4):277-296

Sopkin KL, Stockdon HF, Doran KS, Plant NG, Morgan KLM, Guy KK, Smith KEL (2014) Hurricane sandy: observations and analysis of coastal change. U.S. Geological Survey Open-File Report 2014-1088, p 54

Steyer GD, Cretini KF, Piazza S, Sharp LA, Snedden GA, Sapkota S (2010) Hurricane influences on vegetation community change in coastal Louisiana. U.S. Geological Survey Open-File Report 2010-1105

Steyer GD, Couvillion BR, Barras JA (2013) Monitoring vegetation response to episodic disturbance events by using multitemporal vegetation indices. $J$ Coast Res 63(1):118-130

Subino JA, Morgan KLM, Krohn MD, Dadisman SV (2012) Archive of post-Hurricane Isabel coastal oblique aerial photographs collected during U.S. Geological Survey Field Activity 03CCH01 from Ocean City, Maryland, to Fort Caswell, North Carolina and inland from Waynesboro to Redwood, Virginia, September 21-23, 2003: U.S. Geological Survey Data Series 761, https://pubs.usgs.gov/ds/ $761 /$

Terrano JF, Smith KEL (2015) Estuarine shoreline and barrierisland sandline change assessment. Geol Surv Data Release, U.S. https://doi.org/10.5066/F71Z42HN

Turner RE, Baustian JJ, Swenson EM, Spicer JS (2006) Wetland sedimentation from hurricanes Katrina and Rita. Science 314(5798):449-452
UNEP (United Nations Environment Program) (2006) Marine and coastal ecosystems and human wellbeing. UNEP, Nairobi, p 76

U.S. Geological Survey (2012) Landsat-A global land-imaging mission. U.S. Geological Survey Fact Sheet 2012-3072, p 4

Wahl T, Calafat FM, Luther ME (2014) Rapid changes in the seasonal sea level cycle along the US Gulf Coast from the late 20th century. Geophys Res Lett 41:491-498

Walters DC, Kirwan ML (2016) Optimal hurricane overwash thickness for maximizing marsh resilience to sea level rise. Ecol Evol 6(9):2948-2956

Warren RS, Niering WA (1993) Vegetation change on a Northeast tidal marsh: interaction of sea-level rise and marsh accretion. Ecology 74(1):96-103

Wilson SG, Fischetti TR (2010) Coastline population trends in the United States: 1960 to 2008. U.S. Dept. of Commerce Economics and Statistics Administration, Report P25-1139

Wilson MD, Watts BD, Brinker DF (2007) Status review of Chesapeake Bay marsh lands and breeding marsh birds. Waterbirds 30(1):122-137

Wolner CWV, Moore LJ, Young DR, Brantley ST, Bissett SN, McBride RA (2013) 2013_Ecomophodynamic feedbacks and barrier island response to disturbance: insights from the Virginia Barrier Islands, Mid-Atlantic Bight, USA. Geomorphology 199:115-128

Worm B, Barbier EB, Beaumont N, Duffy JE, Folke C, Halpern BS, Jackson JBC, Lotze HK, Michelie F, Palumbi SR, Sala E, Selkoe KA, Stachowicz JJ, Watson R (2006) Impacts of biodiversity loss on ocean ecosystem services. Science 314(5800):787-790

Wulder MA, Masek JG, Cohen WB, Loveland TR, Woodcock CE (2012) Opening the archive: how free data has enabled the science and monitoring promise of Landsat. Remote Sens Environ 122:2-10 